\title{
Modern dance in Turkey with Geyvan McMillen "Yildız Technical University Dance Program, Cemal Reşit Rey Dance Theater Company and Istanbul Dance Theater Company"
}

Tan Temel ${ }^{1 *}$, Sernaz Demirel Temel ${ }^{2}$,

Faculty of Art and Design, Department of Music and Performing Arts, Dance Program, Yeldı Technical University, Turkey

\section{Article Info}

Received: 03 May 2021

Revised: 08 June 2021

Accepted: 11 June 2021

Available online: 15 June 2021

Keywords:

Choreography

Geyvan McMillen

History of Dance

Modern Dance

Turkey

2717-8870/ C 2021The Authors. Published by Young Wise Pub. Ltd. This is an open access article under the CC BY-NC-ND license

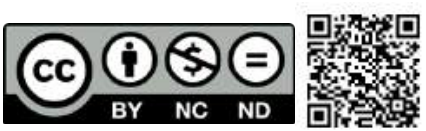

\begin{abstract}
Geyvan McMillen, who has made great contributions to the development of modern dance in Turkey, apart from her activities in State Opera and Ballets, has established her own independent companies and staged her own choreographies in every period of her life. For the sake of revealing the quality of movement she desires to use in her choreographies, Geyvan McMillen has given great importance to the technical training of her dancers. Based on bodies taught in line with these techniques, she has provided her choreographies with distinctive genuineness. Considering technical education and original production as integral, Geyvan McMillen has established the Yildız Technical University Art and Design Faculty Dance Program in 1998 in line with this vision. This program is significant in terms of the artist's artistic journey. In 2002, she has founded the first professional ensemble, Cemal Reşit Rey Dance Theater Company, made up of students trained under the technique she has developed. In 2005 the artist has further founded and directed the Istanbul Dance Theater Company. This article summarizes Geyvan McMillen's contributions to the art of dance in Turkey and the most important outputs of her art vision; namely the university program she has introduced and her work with independent groups she has founded in the 2000s.
\end{abstract}

\section{To cite this article}

Temel, T., \& Demirel Temel, S. (2021). Modern dance in Turkey with Geyvan McMillen "Yildız Technical University Dance Program, Cemal Reşit Rey Dance Theater Company and Istanbul Dance Theater Company". Journal for the Interdisciplinary Art and Education, 2(1), 75-103. DOI: http://dx.doi.org/10.29228/jiae.16

\section{Introduction}

Geyvan McMillen is one of the pioneers that stands out when we talk about the art of modern dance in Turkey. After graduating from Ankara Hacettepe State Conservatory in 1960, she has firstly worked at the Ankara State Opera and Ballet. As of 1977 she has started working for the Istanbul State Opera and Ballet. She has dedicated her whole life to the development of the art of dance in our country, from classical ballet to modern dance, with her several identities such as a dancer, choreographer, an instructor and an art director. During the period 1960-1970 being an artist of Ankara State Ballet, she has danced in several productions: Coppelia, Les Sylphides, Les Patineurs, The Rake's Progress, Assembly Ball, Sleeping Beauty, Checkmate, Les Rendezvous, Çeşmebaşı (At the Fountain), The Burrow, Giselle, Swan Lake, Sylvia, Prince of Pagodas, Blood Wedding, The Nutcracker. (Demirel Temel and Temel, 2021:41)

\footnotetext{
${ }^{1 *}$ Corresponding Author: Assoc.Prof., Yildız Technical University, Faculty of Art and Design, Department of Music and Performing Arts, Dance Program, Turkey. ttemel@yildiz.edu.tr ORCID: 0000-0001-5164-0292

${ }^{2}$ Assoc.Prof. Yildız Technical University, Faculty of Art and Design, Department of Music and Stage Arts, Dance Program, Turkey. sernazd@yildiz.edu.tr ORCID: 0000-000 3-3747-9716
} 


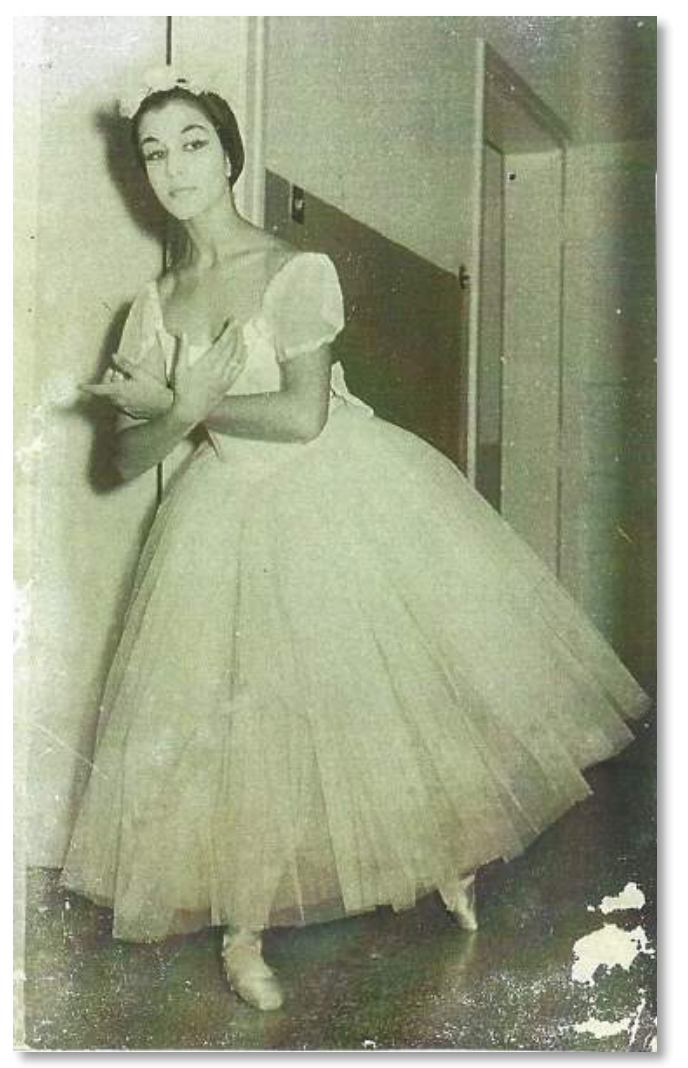

\section{Figure 1.}

Geyvan McMillen in "La Sylphide" Ballet, 1963, Ankara State Opera and Ballet. Retrieved from Her Personal Archive, Courtesy of Geyvan McMillen

The artist who decided to study modern dance between 1970-1974, travelled to London in 1970 with the scholarship she earned. She studied Martha Graham's Technique at London Contemporary Dance School ${ }^{3}$ for four years with Robert Cohen, the artistic director of the London Contemporary Dance Company, and Jane Dudley, the school's Graham head teacher. While she was studying at the London Contemporary Dance School, during the summer courses held at the school she came across the Cunningham Technique. She was highly impressed with the Cunningham dance technique and experienced the technique to be much more suitable for her own body. McMillen, who wanted to get a more detailed training on Cunningham Technique, went to New York in 1973 and started taking lessons at the Merce Cunningham Dance School. The artist, attracting the attention of Merce Cunningham in these lessons, received a one-year scholarship from him and took a break from her school in London to continue her studies in New York. 


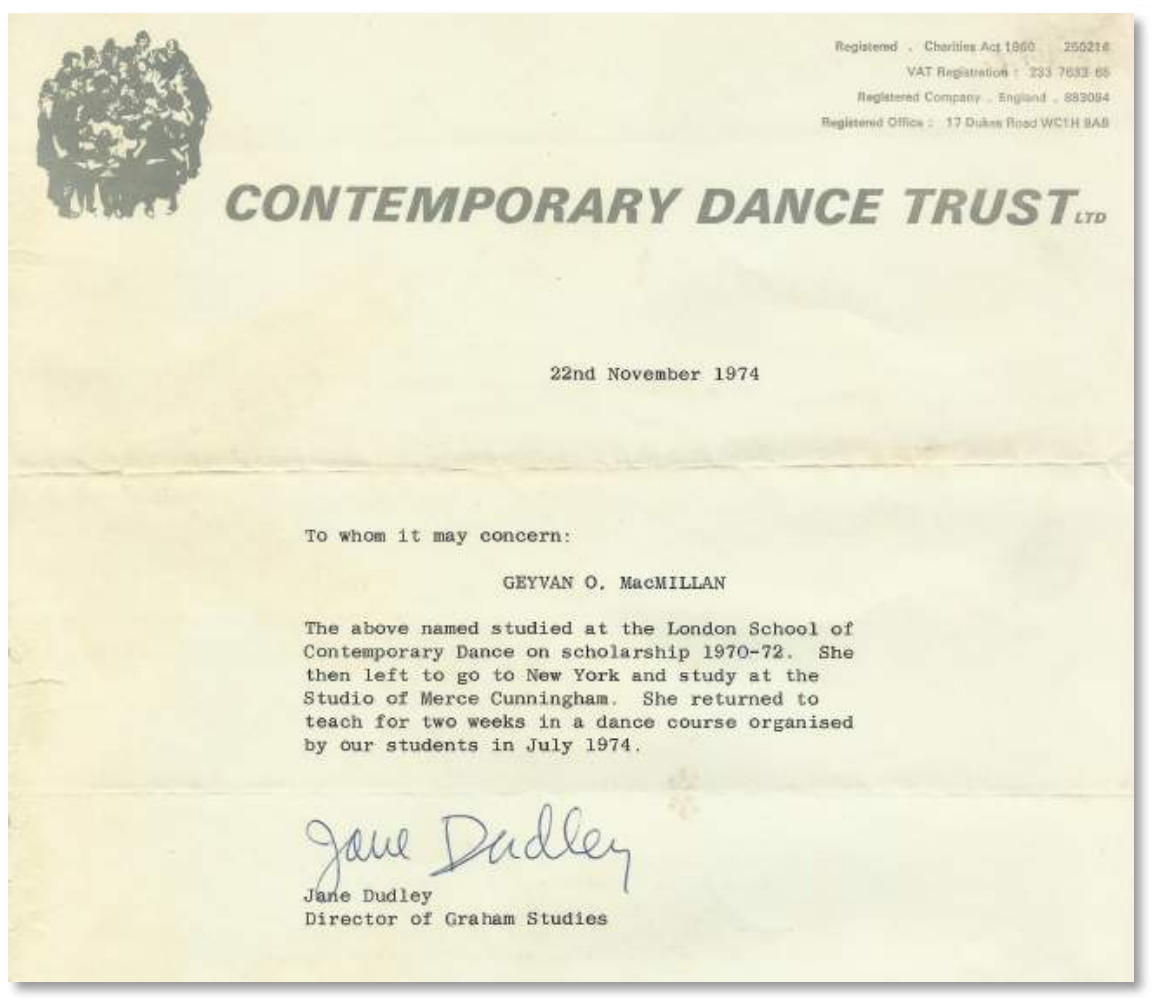

Figure 2.

London Contemporary Dance School, Jane Dudley, Director of Grabam Studies, Letter by Jane Dudley to Geyvan McMillen About Her Studies for Graham and Cunningham Techniques, 1974. Retrieved from Her Personal Archive, Courtesy of Geyvan McMillen

After graduating from London Contemporary Dance School, in late 1974, McMillen returned to her duty in the Ankara State Opera and Ballet in Turkey. McMillen, who wanted to share her five years of modern dance education experience with dancers in Turkey, started to teach modern techniques to aspiring dancers of the Ankara State Ballet willing to work on a different technique and to students of Hacettepe University State Conservatory. We could easily say that these years were the first years of modern dance lessons to be given academically in Turkey ${ }^{4}$ (Demirel Temel and Temel, 2021:34-35). As of 1977, McMillen, decided to continue her studies at the Istanbul State Opera and Ballet. She organized contemporary dance performances with dancers of the Ankara and Istanbul State Opera and Ballets who wanted to work with her. She staged her choreographies by establishing independent companies outside of the State Ballet in Istanbul.

4 'First Steps of Modern Dance In Turkey And Pioneering Works Of Geyvan McMillen' Eurasian Academy of Sciences Eurasian Art and Humanities Journal, 2021, Vol.14 Pg. 34-35

http://arthum.eurasianacademy.org/dergi//turkiyede-modern-dansin-ilk-adimlari-ve-geyvan-mcmillenin-oncu-calismalari202104.pdf 


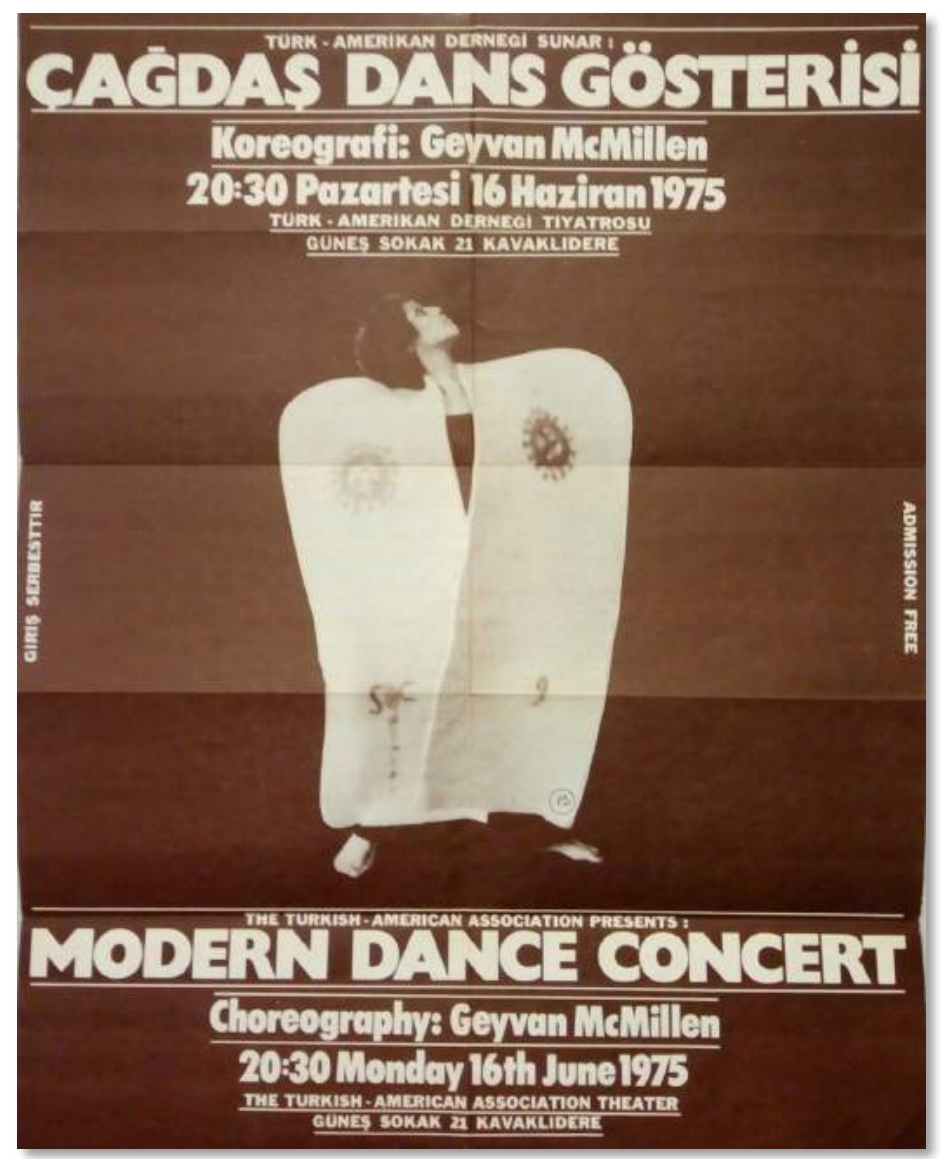

Figure 3.

Poster of the Geyvan McMillen's Modern Dance Concert in 1975. Retrieved from Her Personal Archive, Courtesy of Geyvan McMillen

Until her retirement from Istanbul State Opera and Ballet in 2006, in addition to several managerial and artistic consultancy positions, throughout her artistic life, McMillen also worked as an instructor at universities and conservatories for the development and popularization of modern dance in Turkey. In 1998, upon an invitation of her close friend, painter Prof. Tomur Atagök, she founded Turkey's first Modern Dance Program at Y1ldız Technical University (YTU) Faculty of Art and Design, Department of Music and Performing Arts. This was the first program to provide its students with modern dance education apart from conservatories. This academic program founded by Geyvan McMillen was a convenient environment where the artist had the opportunity to convey all her knowledge through her own artistic vision in the mastery period of her long-term art life. On the second year of the school, starting off in the year 2000, YTU Dance Theater Laboratory served as a platform for students to meet local and foreign choreographers and present their works. This start, made by the artist with a small staff of instructors and limited studio facilities has led to the first steps of the founding of Cemal Reşit Rey Dance Theater and Istanbul Dance Theater Companies together with her students.

In this article summarized, Geyvan McMillen's works between 1998 and 2012 and her contributions to the dance art in Turkey.

\section{Y1d1z Technical University Dance Program (1998-2008)}

Geyvan McMillen has had a great desire for tutoring and choreography since 1960, the year of her graduation from Hacettepe State Conservatory. This desire has given direction to her dance life and has resulted with a motivation always seeking for the authentic and the new. Returning to Turkey after five years of modern dance education in England and America, McMillen has given practical lectures on modern dance technique and theoretical lectures on dance and performance arts at Hacettepe University, Yıldız Technical University, Boğaziçi University, Istanbul University and Istanbul Technical University. She has staged her works with students she has educated. 


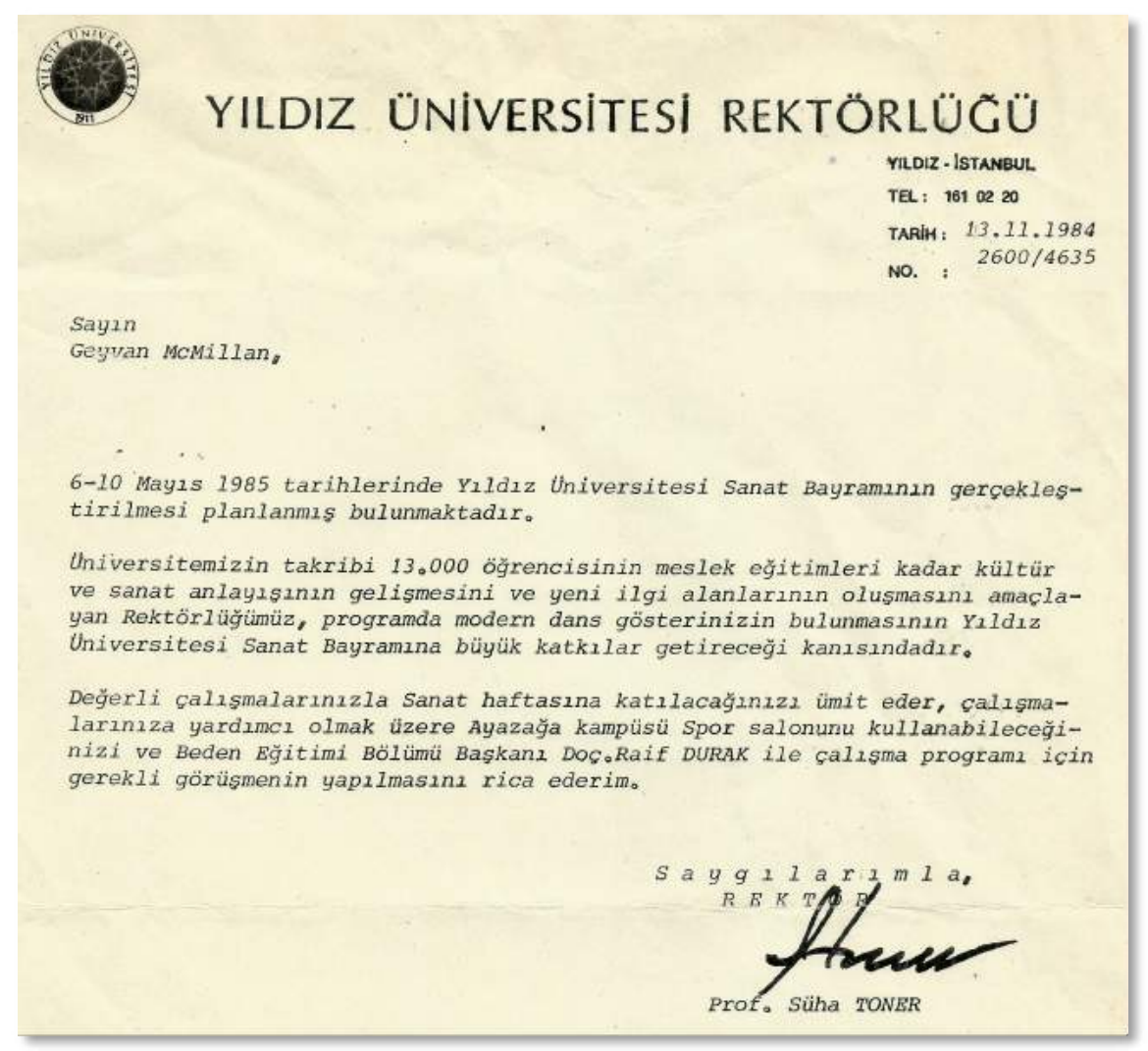

Figure 4.

Letter from the President of the Yuldız University Prof. Süha Toner to Geyvan McMillen, 1984. Retrieved from Her Personal Archive, Courtesy of Geyvan McMillen

Mehmet Sander and Mustafa Kaplan, who can be considered as second-generation names in modern dance in Turkey, have been students of Geyvan McMillen in the 1980s. These artists still continue with their production in the field of dance and performance arts.

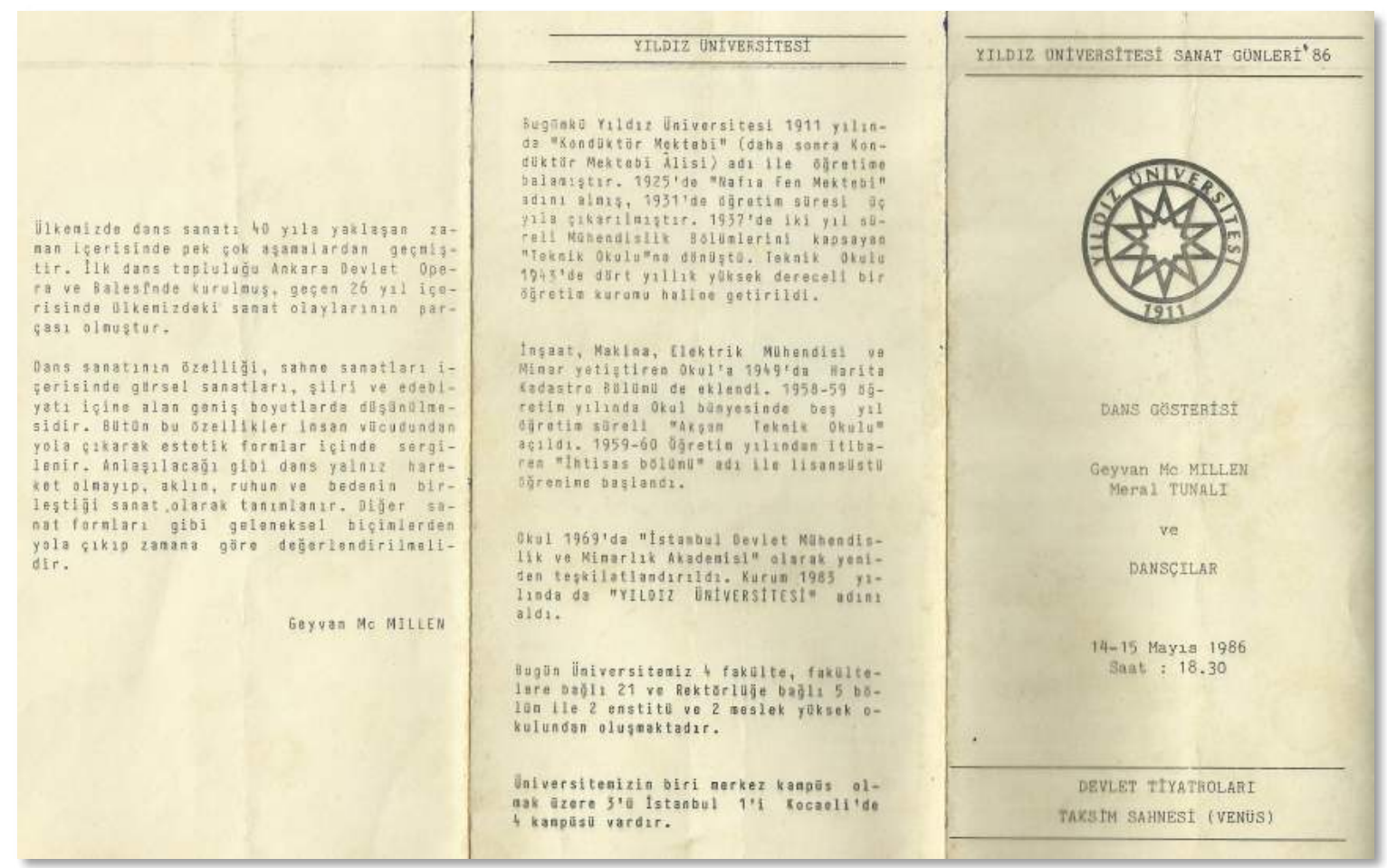

Figure 5.

Program Brochure of McMillen's Performance Together with Her Students at Yuldiz Technical University, 1986. Retrieved from Her Personal Archive, Courtesy of Geyvan McMillen 
McMillen has taught at Mimar Sinan University State Conservatory, Modern Dance Department (now MSU Fine Arts University, Modern Dance Program) until 1998. This has been the first institution where academic education in modern dance has begun in Turkey in 1991. This program, which has had very few students at first, was observed to attract great attention within a few years.

"Modern dance in Turkey will definitely go somewhere. The Department of Modern Dance bas been providing education under the Ballet Department at MSU since five years. It has had its first graduates this year. Actually, this department should have been founded 10-15 years ago, more dancers should have been trained. But we are still taking baby steps. State Opera and Ballet institutions should have modern dance sections. I've been working on this since the '70s. Finally, MDT was established in Ankara. Even this was a belated step. Modern dance should be included in all. It is necessary to provide opportunities for growing dancers. I don't want to compare modern dance in Turkey with its western equivalents. Western countries have been dealing with dance art since the beginning of the $20^{\text {th }}$ century. It has spread from the USA to Europe and has firstly started as a reaction to ballet. They are far abead now. Our dancers are ready for modern dance. Many young people are interested in this practice. They try to do it all by themselves. Yet they must definitely be trained. For this reason, Modern Dance Departments should be established in all universities providing fine arts education." (Geyvan McMillen Personal Notes, 1995, Istanbul)

The work on the establishment of Yildız Technical University Faculty of Art and Design were carried out by rector of the university Prof. Dr. Ayhan Alkış and the commission set up and led by him in 1997. Geyvan McMillen, who was invited by commission member Prof. Tomur Atagö ${ }^{5}$ to create a modern dance program, laid the foundations of an academic dance program where she could develop her own system and school. McMillen always put great emphasis on the dancers developing their own unique body language. This approach, which can be defined as creative dancing, requires the dancers to be educated intellectually. Believing that dancers would develop better intellectually under an interdisciplinary faculty approach, McMillen aimed to create an education platform where new artist candidates who could contribute to the field of modern dance would be trained. A modern dance program to be established with this infrastructure would enable this goal (Geyvan McMillen, Personal Communication, 18 April 2020, Istanbul)

TEȘEKKÜR

Üniversitemizin dünyadaki çağdaş gelişmelere paralel olarak daha üretken bir yapıya dönüşebilmesinde Komisyon üyelerimizin yaptığı çalışmalar önemli bir katkı oluşturacaktır. Değerli arkadaşlarımızın görüş ve eleştirilerini alabilmek amacıyla Sanat Fakültesi Yapılanma Komisyonu'muzun raporiarını yayınlıyoruz.

Bu çalışmalara katılmak suretiyle değerli katkılarını esirgemeyen değerli komisyon üyelerine teşekkürü borç bilirim.

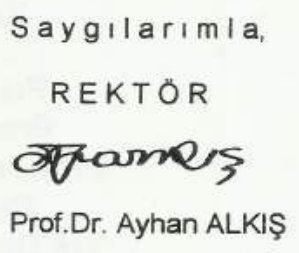

Figure 6.

Letter from The President of The Yaldaz Technical University Prof. Dr. Ayhan Alkess to Commission Members, $1997^{6}$. Retrieved from Her Personal Archive, Courtesy of Geyvan McMillen

McMillen left MSU in 1998 and then established a Dance Program under the umbrella of Yildı Technical University. Established with a new approach alternative to conservatory education, this Dance Program became a school that trained many of Turkey's third generation dancers, who are still actively dancing, producing academically and artistically in the field of modern dance in our country today. Geyvan McMillen, Carlotta Arıcanlı, Kaya İlhan

\footnotetext{
${ }^{5}$ Prof. Tomur Atagök has been served as the Dean of YTU Art and Design Faculty between 2004 and 2006. http://tomuratagok.com/biyografi.php?l=en ${ }^{6}$ Translation: The work of our commission members will make an important contribution in carrying our University to a more productive structure in parallel to contemporary developments in the world. We thereby publish the reports of the Art Faculty Restructuring Commission for the purpose of receiving the opinions and criticisms of our dear friends. I would like to thank our esteemed commission members who have participated in these studies, for their valuable contributions. Prof. Dr. Ayhan ALKIŞ
} 
and Zeynep Tanbay have been the first instructors of this Dance Program, which has been initiated with very limited physical and academic staff opportunities.

McMillen, later on has included in her staff Tan Temel ${ }^{7}$, Alev Meral Tokgöz, Nur Berkan (Istanbul State Ballet), Oktay Keresteci (Istanbul State Ballet), Uğur Seyrek (Istanbul State Ballet); and in theory classes Zeynep Günsür, Leman Yilmaz. YTU Modern Dance Program has become known in Turkey and in the world in a short time due to its strengthened staff under the direction of McMillen.

Table 1.

YTU Dance Program 1998-1999 Instructors of the Academic Staff

\begin{tabular}{llll}
\hline Academician/Artist & Lectures & & \\
\hline Instructor Geyvan McMillen & Modern Technics, Classical Ballet, Composition, Repertoire, \\
& Improvisation & \\
Instructor Carlotta Aricanlı & Classical Ballet, Floor Barre & \\
Instructor Kaya İlhan & Modern Technics, Movement Laboratory & \\
Instructor Zeynep Tanbay & Graham Technic & \\
\hline
\end{tabular}

McMillen invited world-renowned trainers and choreographers to the YTU Dance Program to ensure that her students were trained in the most well-equipped way during their four-year undergraduate education, which is actually a short period of time for dance education.

"Four years is never enough to become a good dancer. Another four years of study and dancing is essential on top of school education. Only after the eighth year, things start to come." (Geyvan McMillen,Personal Communication, 18 April 2020, Istanbul)

Lutz Foster from Pina Bausch Dance Company, Paul Clayden, Liam Steel from DV8 Physical Theater Company, Juan Kruz de Garaio Esnaola, Luc Dunbery from Sasha Waltz Dance Theater Company, Ismale Ivo, Founder and Director of ImpulzTanz Festival, Gary Galbraith one of the dancers of the Martha Graham Dance Company, Karen Potter from the Limon Dance Company, Matthew Hawkins one of the dancers of the Royal Ballet Dance Company, Loretta Livingston one of the lecturers of the University of California Dance Department, Leslie Peck from the New York City Ballet dancers, Nicole Caccivio, Helen Omand continuing their studies in Europe, Louise Frankenhuis, Hilke Diemer, Jack Gallagher instructors of the Rotterdam Dance Academy, Tetsuro Fukuhara who continues his studies in Japan, Diether Heitkamp one of the instructors of the Frankfurt University Music and Performance Arts Department, Martin Kravitz one of the former dancers of the Batsheva Dance Company, are renowned dancers who have participated as guest instructors at the YTU Dance Program.

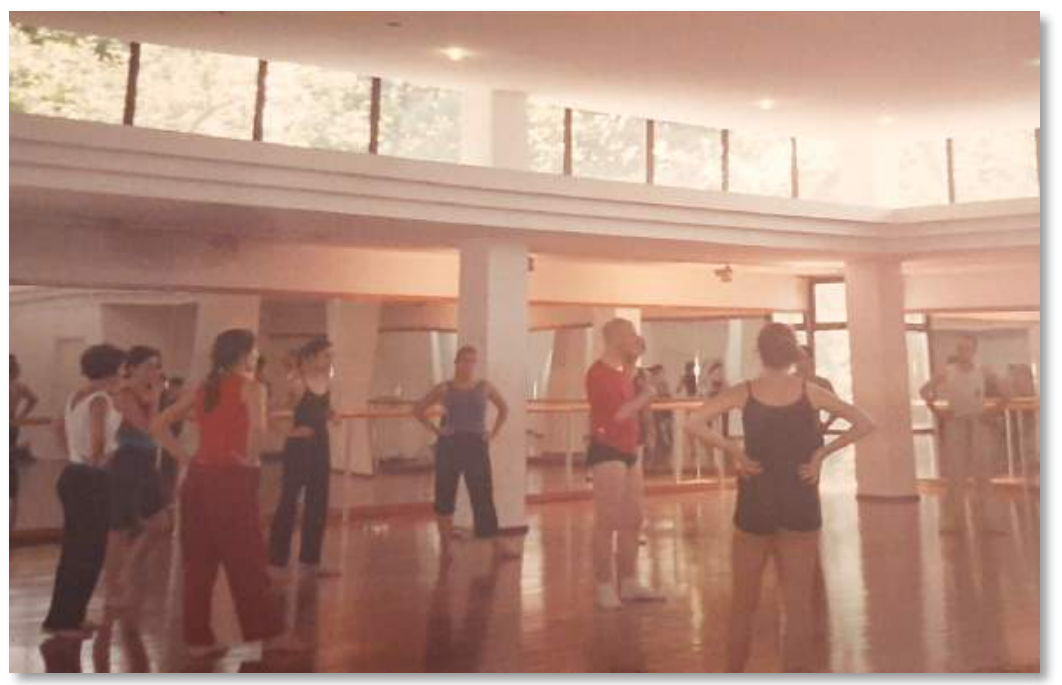

\section{Figure 7.}

YTU Yüksel Sabancu Art Center Dance Studio, Dance Students are Together with Guest Teacher Matthew Hawkins. Retrieved from the Personal Archive, Courtesy of Tan Temel \& Sernaz Demirel Temel

\footnotetext{
7 'I met Geyvan McMillen during the period when she was teaching at Mimar Sinan. It was a period when I was an extra at the Istanbul State Opera and Ballet and danced in children's ballet pieces (1991-1997). My friends, who were students of the Conservatory Ballet Department, had supported me and motivated me to join the school. I had the opportunity to meet the Head of Ballet Department, Alev Meral Tokgöz in my first visit to the school. She directed me to modern dance classes given at Taksim Aksanat. I was told that Kaya Ilhan and Geyvan McMillen also allowed outside participants there and that it would be good for me to prepare for school by attending these classes. Therefore, my dance lessons began during the spring of 1995. There is one thing I remember very clearly from that very year when I took my first step, McMillen's discipline, her passion and Kaya Illhan's incredible energy, with which I had a hard time keeping up with even though I was only 18 years old. They impressed me a lot." (Tan Temel, Personal Notes, 2020, Istanbul)
} 
McMillen has received invitations from festivals such as the Jonge Dance Festival organized by the Rotterdam Dance Academy and the International Dance Schools Meeting held in Essen, Germany. Together with her students she has participated in these festivals. YTU Dance Program students have had the opportunity to receive lessons from instructors working in Europe and also have had the chance to stage their work at school. In these festivals attended by long-established and well-equipped schools of Europe, despite their limited educational opportunities Yildız Technical University students have been well appreciated and their work has received significant recognition.

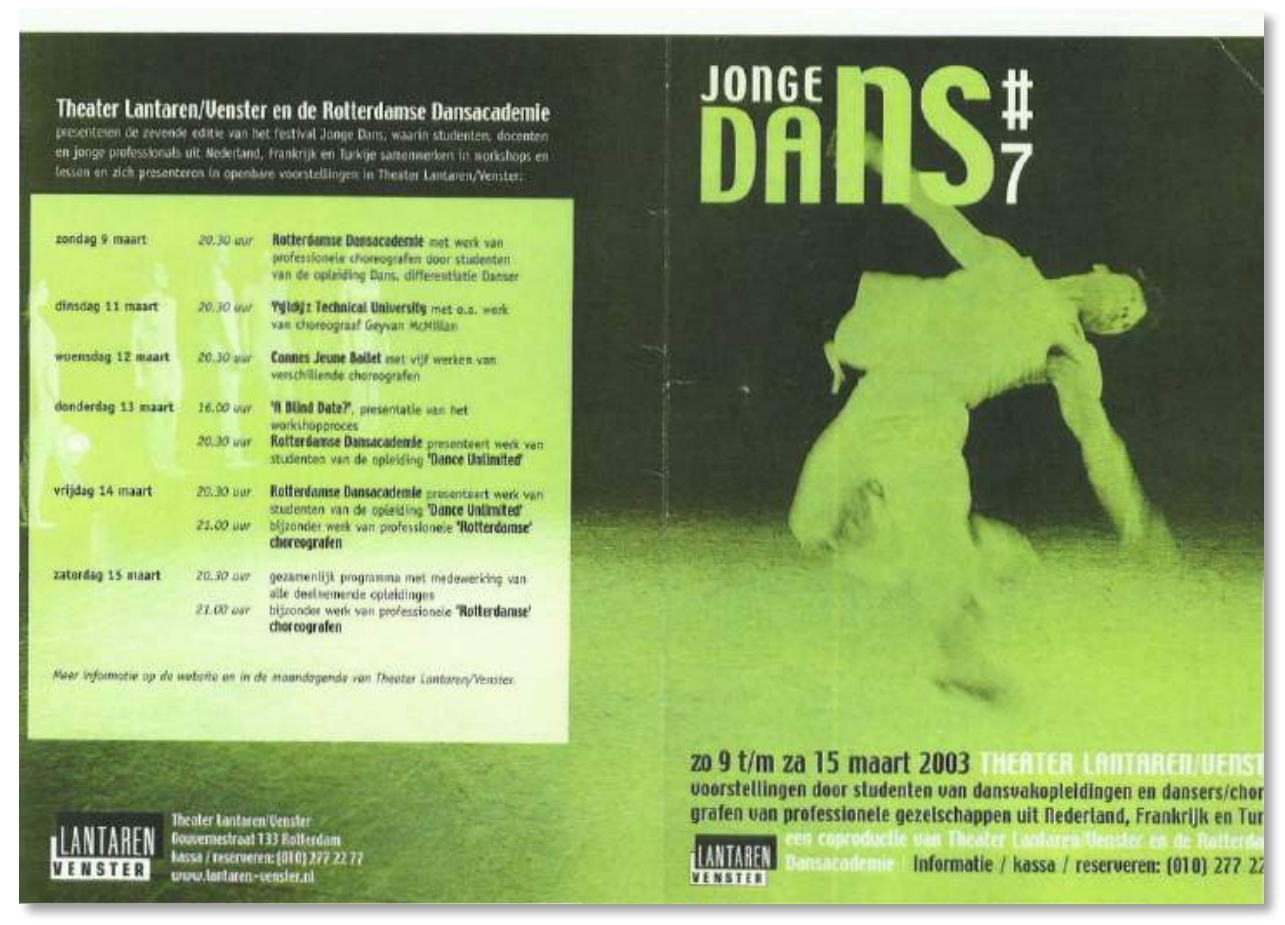

Figure 8.

Festival Brochure, YTU Dance Theater Laboratory, Attendance of $7^{\text {th }}$ International Jonge Dans Festival. Retrieved from the Personal Archive, Courtesy of Tan Temel \& Sernaz Demirel Temel

YTU Dance Program is the work of mastery of Geyvan McMillen. It is shaped by her artistic vision and her experience as an instructor and choreographer acquired over the years. Thanks to events held on national and international platforms, this program has lent great impetus to the development of the art scene of Istanbul in the beginning of the 2000s. This period can be described as "the golden years of modern dance in Turkey".

Owing to festivals and organizations organized by theatres in Istanbul, as well as university events held at YTU, school productions have also found an opportunity to meet their audiences outside. These studies, carried out as YTU Dance Theater Laboratory, have constituted the foundations of the professional dance company that Geyvan McMillen has dreamt of for the future. 


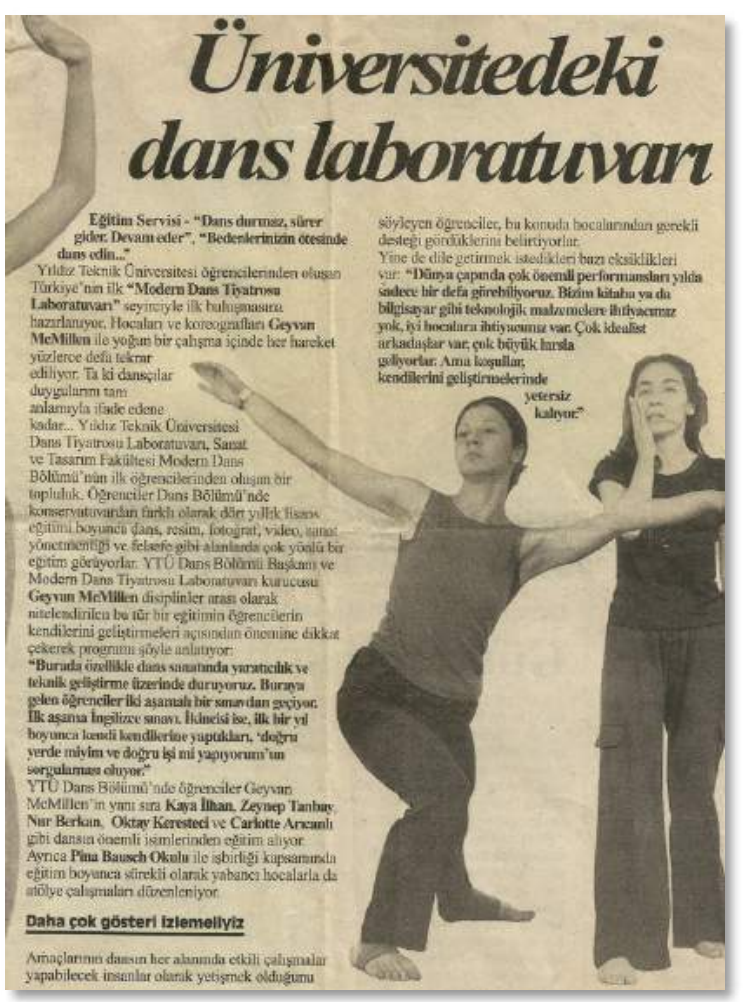

Dance Laboratory in the University

Figure 9.

Cumburiyet Newspaper, 2001. Retrieved from Her Personal Archive, Courtesy of Geyvan McMillen

The founding vision of YTU Art and Design Faculty was to enable arts students to combine various disciplines with their own majors, within the framework of an interdisciplinary approach. The YTU Art and Design Faculty was Turkey's first Art and Design Faculty when it was established in 19978. Thus, it provided dance students with cultural lessons apart from their own field. This in turn would contribute to their intellectual development and encourage them to share their creations and produce projects in different fields such as music, painting, sculpture, photography and video.

"The most important reason why I wanted to establish the program within the body of a university was because this would give the students a chance to work together with other disciplines of fine arts. It was very important for me that the students were trained as well-equipped students who would easily adapt to the developing art world and be inspired by it. Because I always attach importance to students perceiving life and art not only in terms of dance, but also from a multi-faceted perspective, and it is essential that they are educated both intellectually and creatively." (Geyvan McMillen, Personal Communication, 18 April 2020, Istanbul)

Due to the lack of instructors trained in the field of modern dance, McMillen made a selection from among the students trained by herself and put together a staff of instructors from the graduates of YTU. ${ }^{9}$

\footnotetext{
8 http://www.sts.yildiz.edu.tr/sayfa/1/Hakkimizda/85

9 "Geyvan McMillen, together with Kaya IIlhan, would choose the most hardworking student of that year, give the student a scholarship, and then encourage him/ her to study abroad. This approach enabled the students to further develop their vision and advance technically. This had grown into a tradition which motivated all students in the school to work harder. It was a great support which widened the horizon of students who had scarce chances to go abroad. McMillen used to devote her entire day to students. In the early years of the school there were not enough instructors, so she was responsible for most of the courses. Her biggest goal was to train her students, make them dance as company dancers. That's why I don't remember ever going on a vacation during my student years. She believed that four years of undergraduate education was not enough to become a dancer. She established the Yuldra Technical University Dance Laboratory for that purpose. As we were only one-month dance students, she produced choreographies appropriate for our technical infrastructure in order for us to gain stage experience. The choreographies she creates for us junior dancers, were far beyond student works. She somehow managed to communicate the spirit of her dance to us. Now looking back. at that period, I don't think that this is a virtue possessed by every teacher. McMillen was a person who made her students dance by inspiring them with the group spirit in her classes. She did not regard dance as a separate field from other disciplines. She chose to make her students love art as a whole and always encouraged them to produce in order to become creative dancers. She provided for the staging of the works of her students in school performances held every semester. She personally accompanied her students to performances in biennials, exhibitions and otherperformance spaces and commentated about the art. This shows a sense of ownership far beyond an ordinary trainer would have and that is the evidence of the artist's intense love for her job." (Sernaz Demirel Temel, Personal Notes, 2020, Istanbul)
} 


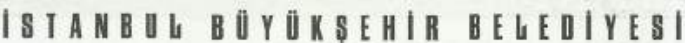 GEMAL REȘIT REY — KONSER SALONU}

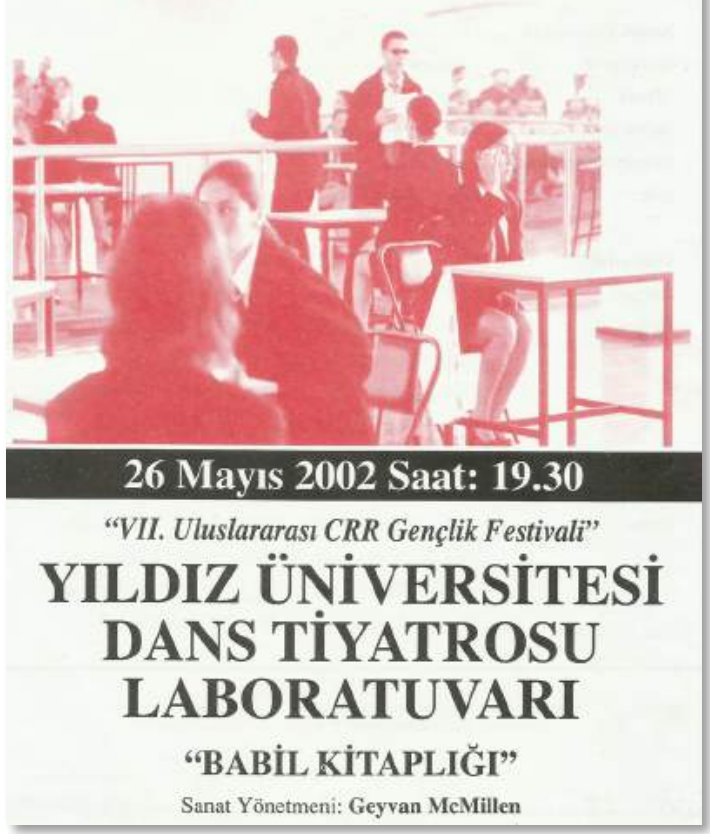

\section{May1s 2002}

YILDIZ ÜNIVERSITESI DANS TIYATROSU LABORATUVARI

"Babil Kitaplığı"

Sanat Yơnetmeni : Gcyvan Mc Millen

Koreograf : Ismael lvo

Mürik : Steve Shehan

Sahneye Koyan : Geyvan McMillen

Dekor ve Kostim ：I Ismael lvo

Işık : Geyvan McMillen

Dansçilar:

Borges : Tan Temel

Iş̧̧iler : Elif Saran, Ayrin Ersöz, Sernaz Demirel, Natalin Boz,

Harika Onur, Onur Topal, Eylem Gülter Yazicı, Senem Oluz, Sanem Ozcan, Pinar Ataer, Punar Güremek,

Burçak Șenel, Ece Özgenel, Nurhan Nebioglu, Arif Aydmls.

Konu : Bir sonsuzluk yolcusu hangi yöne giderse gitsin, yüzyllar sonra aym cittlerin ayn bozuk-dūzende yinelendiğini görecektir (ve böyle bir yineleniș, yeni bir düzene değişecektit. Biricik Düzen'e).

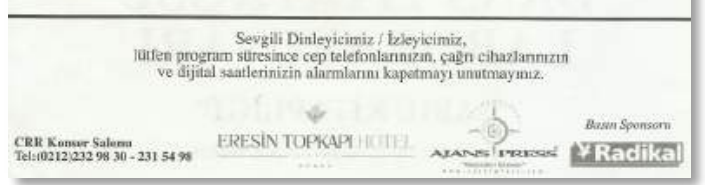

Figure 10.

"Babel Library", Choreography by Ismael Ivo, YTU Dance Theater Laboratory Performance at 7th International CRR Youth Festival, 2002. Retrieved from Her Personal Archive, Courtesy of Geyvan McMillen

Geyvan McMillen completed her master's degree for the "Performance Arts Museum" project, this was a project she dreamt of actualizing in Turkey for many years, during her busy school schedule. Her master's thesis, titled "A Post-Republican Dance Art Department Proposal for a Modern Art Museum to be established in Turkey", is a study on the design of a museum that will serve as an archive of the work in the field of performing arts in Turkey ${ }^{10}$.

McMillen spent great effort to adapt the Dance Program established at Yildız Technical University to a technical university system which was in fact providing education on engineering and science. Issues such as increasing the hours of vocational courses on modern dance, classical ballet, repertoire, improvisation, composition, and fitting physical facilities to international standards can be counted among the difficulties encountered during this period. Despite her expertise as an artist and her influence in terms of achievements, not having an academic title has been an issue for McMillen in acquiring administrative duties in the academic organization of the university. Due to these reasons, the artist has resigned from Yildız Technical University in 2008.

Looking at academic institutions that provide dance education abroad we see that, people who are experts in their art are granted special support so that their artistic production under the umbrella of the institution is encouraged and they continue to educate their students further. The works of experienced artists accumulated along the years and their artist identity, are much more important than their academic identities. Being aware of this, educational institutions give priority to artists who have the potential of increasing their institutional prestige. For example, choreographer Susan Marshall living in New York who did not hold a PhD in art and did not have a prior academic title, was appointed as the Artistic Director of the Lewis Art Center Dance Program at Princeton University. ${ }^{11}$ Also Lutz Föster, one of the first dancers of the world-famous choreographer Pina Bausch's Tanztheater (Dance Theater) Wuppertal Pina Bausch, served as the Artistic Director of the Folkwang University Dance Department from 1992 to $2012 .{ }^{12}$ Unfortunately, a practice as such has not been sufficiently integrated into the system of the universities in Turkey yet.

\footnotetext{
${ }^{10}$ YTÜ Library Catalog, Master Thesis of Geyvan McMillen http://yordam.ktp.yildiz.edu.tr/yordambt/yordam.php?sayfa=sayfaArama\&aDemirbas=0005792

${ }^{11}$ https://www.princeton.edu/news/2009/05/11/internationally-renowned-artists-appointed-head-lewis-center-programs
}

12 https://www.folkwang-uni.de/home/tanz/izt/geschichte/lutz-foerster 
After Geyvan McMillen left the school, according to Council of Higher Education ${ }^{13}$ (CoHE) regulations, in 2011, student admissions to the YTU Dance Program were terminated due to the lack of sufficient number of academic instructors ${ }^{14}$.

\section{Cemal Reşit Rey (CRR) Dance Theater Company (2002-2005)}

CRR Dance Theater Company was founded in 2002 by Geyvan McMillen upon the invitation of CRR General Art Director Arda Aydoğan..$^{15}$ The company has presented to the Istanbul audience four different productions from 2003 to 2005 and has had the opportunity to stage their productions in prestigious international festivals such as the Sarajevo Winter Festival, Chicago Dance Festival and the Bodrum Ballet Festival.

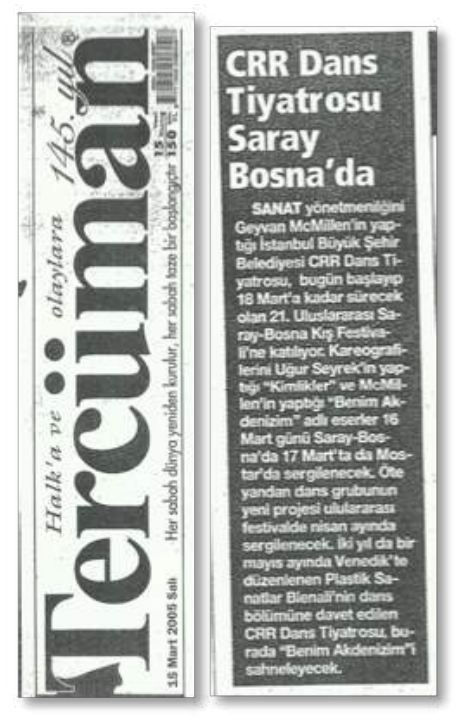

CRR Dance Theater at Sarajevo Winter Festival, Tercüman Newspaper, 2005

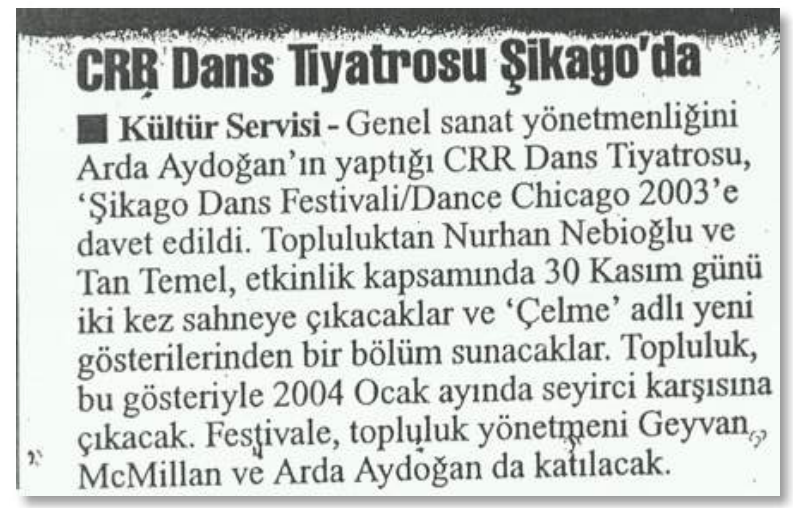

CRR Dance Theater Perform in Chicago, Cumhuriyet Newspaper, 2003

\section{Figure 11.}

\section{News About CRR Dance Theater Company International Performances. Retrieved from the Personal Archive, Courtesy of Tan Temel \& Sernaz Demirel Temel}

The vision of the CRR Dance Theater Company put great importance work with both Turkish and foreign artists. McMillen wished that aside from dancers also choreographers and instructors would be trained within the company. The idea was the maintenance of the work of the company for many years, its persistency and a leading role in the development of modern dance in Turkey. The presence of this company could create momentum in the dance scene and constitute a model for new dance environments to sprout in Turkey. At that time, apart from the Ankara State Opera and Ballet Modern Dance Company ${ }^{16}$, there was no modern dance company established in Turkey. Pieces of dance artists working independently were staged only on project basis. Cemal Reşit Rey Dance Theater Company ${ }^{17}$ became the first modern dance company to fill this gap. The Company was affiliated to Kültür A.Ş.18, one of the private companies of the Istanbul Metropolitan Municipality, which was structurally its financial resource as well. Established with financial and physical support provided under the roof of CRR Concert Hall, the CRR Dance Theatre Group staged important works between the years 2002 and 2005 and contributed to the field of dance in Turkey.

\footnotetext{
13 https://www.yok.gov.tr/en

14 "Being dancers educated by Geyvan McMillen, in our first years at school, we intensely concentrated on dancing, carrying out company work and providing training for students. For this reason, we were just in the beginning of studies that would lead us to progress academically. We were not aware of a possibility that our program would be terminated with such justification. Because we had dedicated ourselves to working to develop the art of dance in our country as well-equipped dancers, trainers and choreographers." (Sernaz Demirel Temel and Tan Temel, Personal Notes, 2020, Istanbul)

15 https://tr.wikipedia.org/wiki/Arda_Aydoğan

${ }^{16}$ https://ekitap.ktb.gov.tr/TR-80133/mdt-doguyor.html

${ }^{17}$ http://istanbuldanstiyatrosu.com/index.php

${ }^{18}$ https://kultur.istanbul/kultur-a-s/
} 


\section{CRR Dans tiyatrosu'na ILGI COK BÜYÜK}

Mayıs ayından bu yana toplam 4 gösteri yapan tiyatro, 800 kișilik Cemal Reşit Rey konser salonu'nu dolduruyor

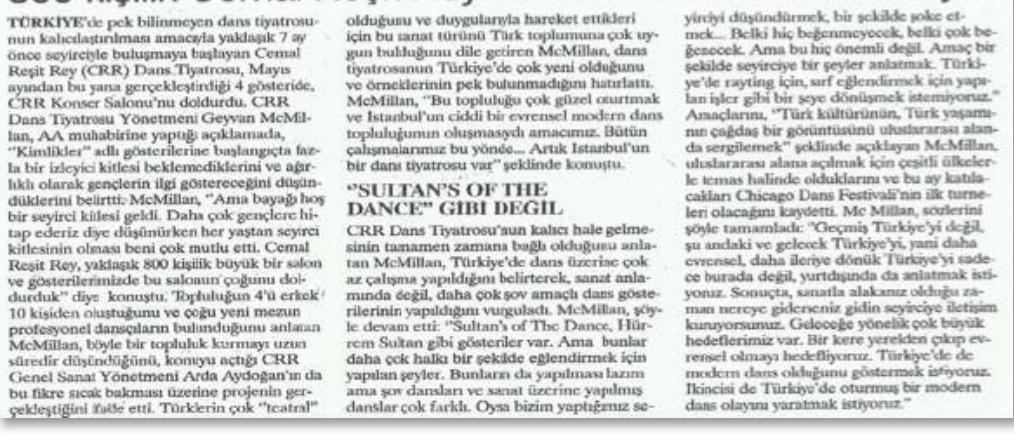

The interest in CRR Dance Theater is huge.

The ensemble, which has performed a total of 4 shows since May, fills the 800-seat CRR concert hall.

\section{Figure 12.}

News about CRR Dance Theater, Dokuz Sütun Magazine, December 5th 2003, p. 13. Retrieved from the Personal Archive, Courtesy of Tan Temel \& Sernaz Demirel Temel

The first practices of the company begun with the YTU Art and Design Faculty, Music and Performing Arts Department Dance Program. The YTU Dance Theater Laboratory which was established by McMillen within the school, prepared its students for a professional company. Mc Millen provided her students with stage experience in festivals at the beginning of the 2000s in a dance environment which was way more active in comparison to today,

In 2003, Geyvan McMillen, Uğur Seyrek, Nicole Caccivio and Paul Clayden created the first production of CRR Dance Theatre Company, namely the project "Identities". This work, which combined four different choreographies under the same concept, was welcome with great interest by the audience. The company gave the Istanbul audience an opportunity to enjoy a dance theater company which was not an ensemble working under the corporate roof of State Ballets.

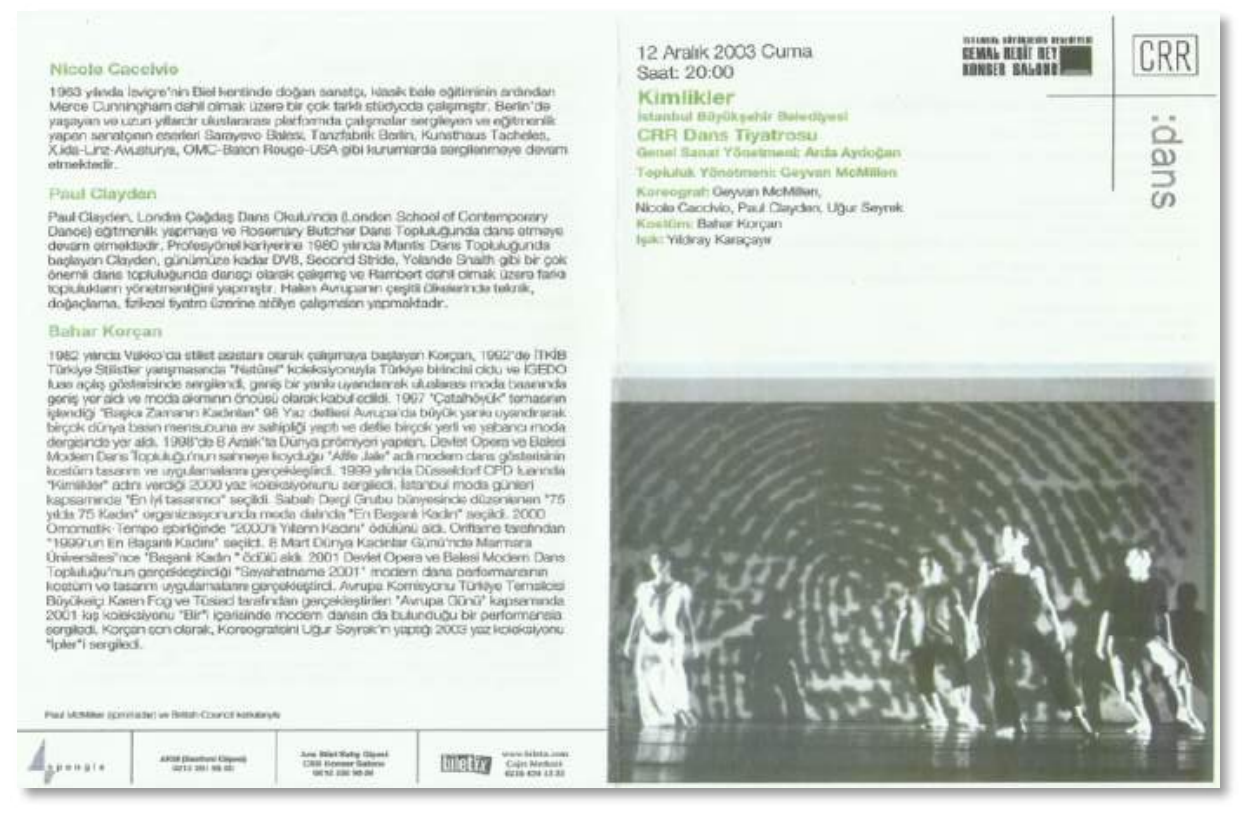

\section{Figure 13.}

Program Brochure of CRR Dance Theater "Identities" Performance, 2003. Retrieved from the Personal Archive, Courtesy of Tan Temel \& Sernaz Demirel Temel

The company meeting its audiences on a regular basis managed to communicate to wider masses the existence of the art of modern dance also on academic level. This was one of its most important impact. Young generation dancers have shown great interest in the company especially because of arising opportunities of employment for them as professionals. In the school admission exams, which occurred after the establishment of the company, a 
significant increase in applications to the YTU Dance Program could be observed. When young candidates were asked about their goals in interviews conducted during these exams, they replied, "I want to dance in the CRR Dance Theater Company". ${ }^{19}$ All these incidents can be considered as an important sign that the right steps had been taken in the course of the development of the art of dance in Turkey.

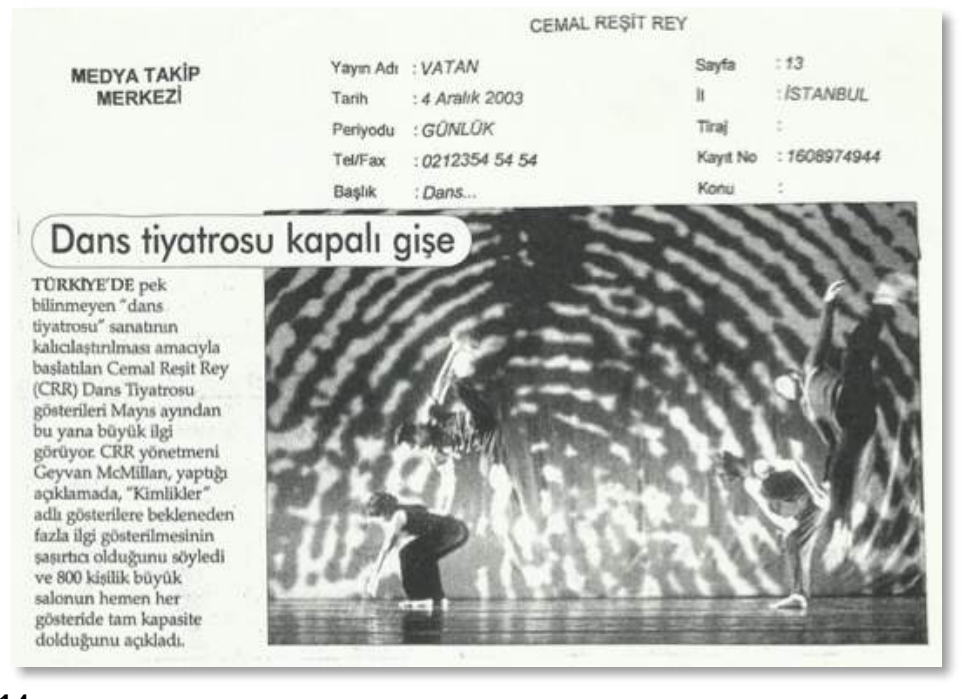

CRR Dance Theater Tickets Sell Out

\section{Figure 14.}

News about CRR Dance Theater "Identities" Performance, 2003. Retrieved from the Personal Archive, Courtesy of Tan Temel \& Sernaz Demirel Temel

CRR Dance Theater Company staged the productions: "Fragile", the choreography of Morgan Belanguer, "My Mediterranean" the choreography of Geyvan McMillen, and "Naked Hamlet" the choreography by Ismael Ivo.

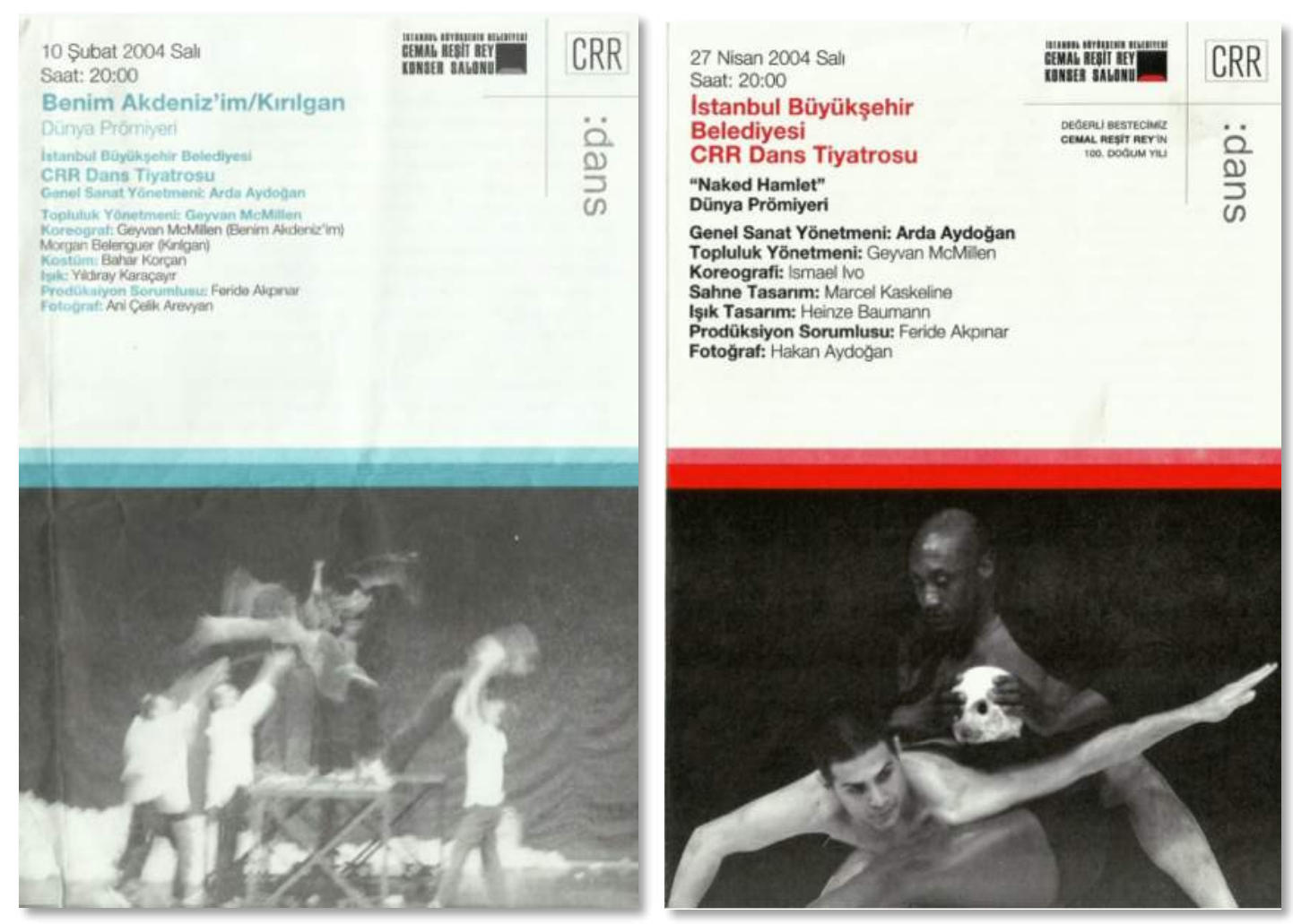

Figure 15.

CRR Dance Theater "My Mediterranean" and "Naked Hamlet" Poster, 2004. Retrieved from the Personal Archive, Courtesy of Tan Temel \& Sernaz Demirel Temel 


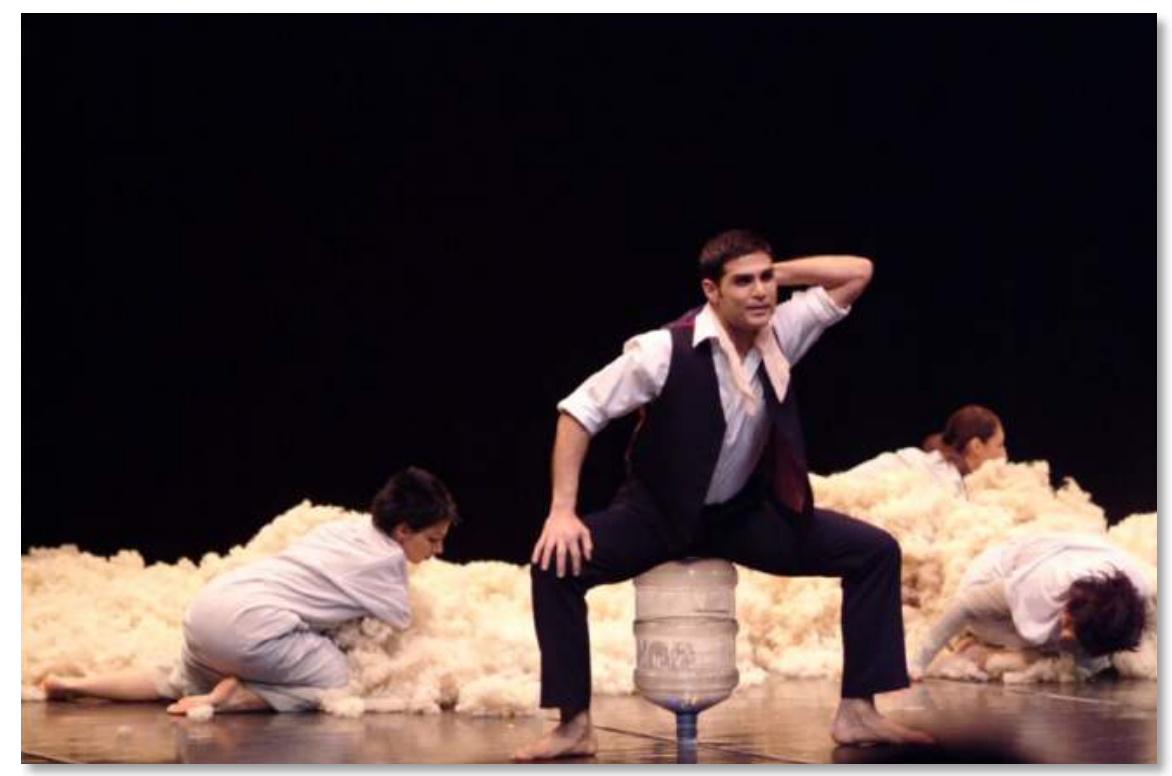

Figure 16.

CRR Dance Theater "My Mediterranean" Choreography by Geyvan McMillen, 2004. Retrieved from the Personal Archive, Courtesy of Tan Temel \& Sernaz Demirel Temel

In 2005, during the rehearsals of the "Flower Fields" project, the fourth production of the group, Istanbul Kültür A.Ş. decided to have sudden staff changes in the management. The new management dismissed CRR Artistic Director Arda Aydoğan and appointed İskender Pala instead. The work of the group was terminated without giving any proper justification and all the planned performances were cancelled. ${ }^{20}$

"The art of dance, that has a very young history in Turkey was not provided with the appropriate environment and infrastructure socially, culturally or economically to realize expansions and formations in compliance with European and world standards. The primary reason for this, is the inability in our country to create a permanent culture and art policy applicable for all branches of art. This infrastructure which does not come into being on country basis, is tried to be implemented by local governments, yet a proper functioning is still not possible due to bureaucracy, systemic and most importantly mentality obstacles. Unfortunately, we as a company, had our share in experiencing this reality of Turkey." (Temel, 2006, p. 42)

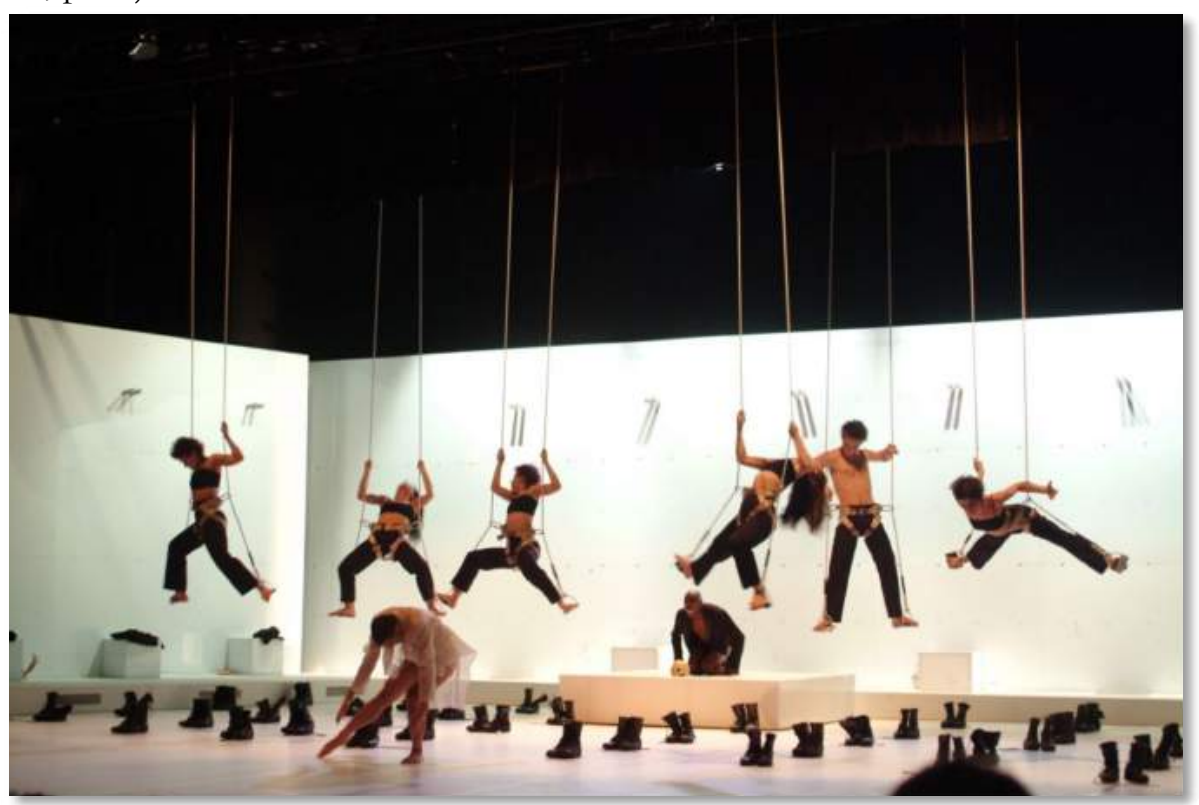

\section{Figure 17.}

CRR Dance Theater "Naked Hamlet" Choreography by Ismael Ivo, 2004. Retrieved from the Personal Archive, Courtesy of Tan Temel \& Sernaz Demirel Temel

\footnotetext{
${ }^{20}$ Tan Temel, "We received the news about the shutdown and termination of activity of the CRR Dance Theater Company in an unexpected moment during the rehearsals of our new work, "Flower Fields", choreographed by Geyvan McMillen. It was difficult for us to fully understand and digest this sudden situation while still working on the project. The hardest part for me was the phone call I received right after the news of the shutdown. I was told to collect and pack all our costumes and materials in the house. Having to carry everything I could to our studio at YTU, I really felt offended. It was truly a difficult experience for me to see in an instance how much we had accumulated in a short period of time like three years."
} 
In the early 2000s, CRR Dance Theater Company brought great dynamism to the Istanbul art scene. It can easily be said that between 2003 and 2005, i.e. during the staging period of its productions, the company was a pioneering culture and art project that was implemented with an art vision and contemporary approach that had the ability to sustain its effect for longer periods. It is obvious that the CRR Dance Theater Company acted as an institution capable of meeting the needs of young generation dancers under dance education in the field of performing arts as well as the Istanbul audience. In this respect, it definitely deserves a major position in the Turkish Modern Dance History literature. This period also played a big role in the formation of substantial behind-the-scenes teams, working and gaining experience in the field of performing arts. It is an undeniable fact that the decision to shut down a dance company, which has succeeded in presenting its productions to larger audiences and in a respectively short time period has attracted the attention of international art platforms, resulted with a serious gap in Turkish Modern Dance studies and practices.

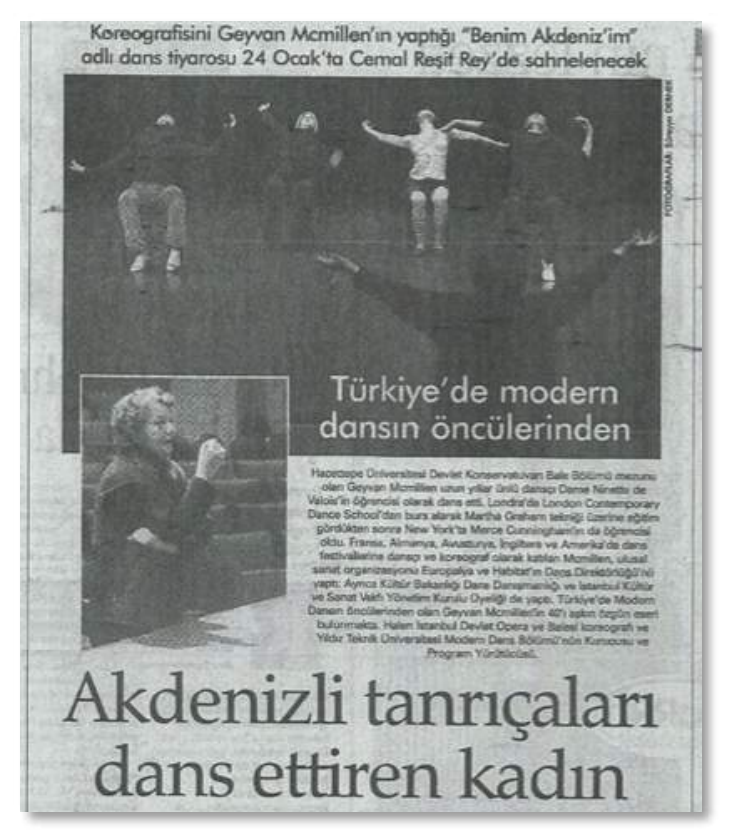

Figure 18.

Vatan Newspaper, January 10th 2004
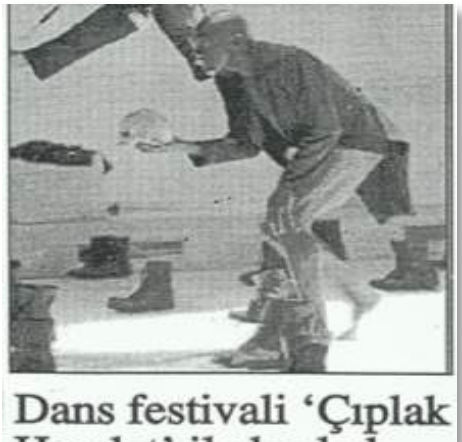
Hamlet' ile başladi

4. Uluslararası Istanbul Dans Festivali, Cemal Reşit Rey (CRR) Konser Salonu'nda başladı. lstanbul-AA CRR Konser Salonu Genel Sanat Yơnetmenlifince durenlenen festivalin açling gecesinde, CRR ked Hammet'(Ciplak Hamilet) adtit gosternyi anhnele-
di. Feativalde is Nisan'da Antalya Deviet Opera ve di. Feativalde 28 Nisan'da Antalya Devlet Opera ve
Baleai, 29 Nisan 'da Compagnie Fatee Galantes, 30 Nisan'da Compagnia Balletto Classico, 1 Mays' ta Theatre dans severierie bulusacak.

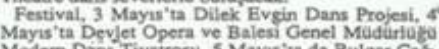
Modern Dins 'Tiyatrosu, 5 Mayis'ta da Bulgar Ca cek.

Istiklal Newspaper, May 2nd 2004

News About CRR Dance Theater Company Retrieved from the Personal Archive, Courtesy of Tan Temel \& Sernaz Demirel Temel

"Dance companies are the best circles for dance artist candidates who receive education in universities and conservatories to perform their art. In this sense, each and every company established contributes to the existing lack of our country in this regard. As a young dance artist, my greatest wish is to see in a city like Istanbul, which is a world city of multicultural structure, that not only the CRR Dance Theater Group, but also all other qualified groups aiming to develop the art of dance get support." (Temel, 2006, p. 43)

\section{Istanbul Dance Theatre Company - IDT (2005-2012)}

"My art will exist wherever I am." (Geyvan McMillen, Personal Communication, August 5, 2020, Istanbul) This was something McMillen always suggested to her dancers. The rehearsals of the CRR Dance Theater Company had been suspended, but it was not possible to stop working. McMillen received an invitation from the Venice Biennale Dance Festival. A smaller company producing for professional platforms would be formed. So, McMillen founded the Istanbul Dance Theater Company in 2005 and continued to stage her choreographies along with her dancers.

"IDT is actually a continuation of CRR Dance Theater. I founded my very first contemporary dance ensemble with a small group in Ankara State Ballet in 1974. Thereafter I formed small companies once at Istanbul State Ballet and once at Yildiz. Technical University. To give an example, nice artists such as Mehmet Sander and Deniz Berge emerged from the company we founded in 1984. My fourth group was the CRR Dance Theater Company. Upon a proposal from Arda Aydoğan, we started working in 2002. But in April 2005, following the change in management, for unknown reasons we were told that we could no longer continue working there. What was the problem, did they not want dancing there, it is now question mark to me. But nevertheless, reality is that they all of a sudden sort of erased all our hard work there. But of course, dance was not over for us, and so we immediately went on to establish the IDT." (Bay, Milliyet Sanat, 2006, p.46) 


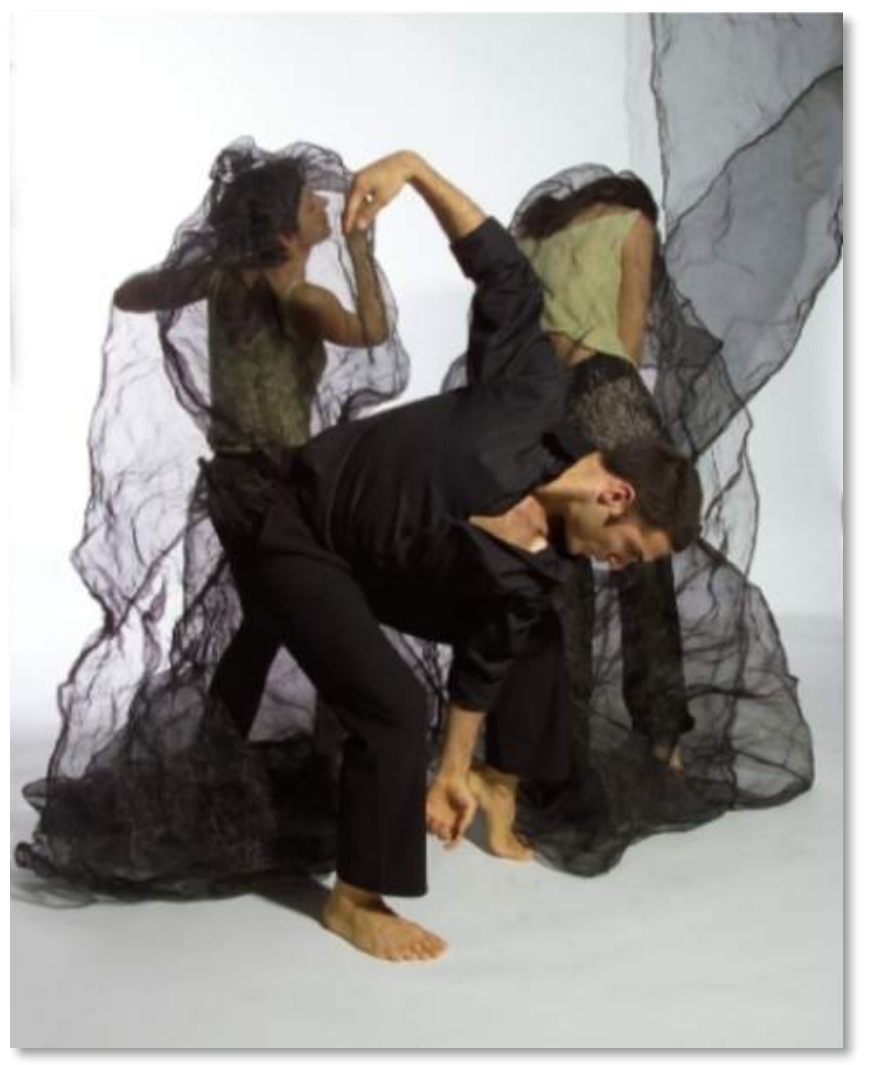

\section{Figure 19.}

"The Hidden" Choreography by Geyvan McMillen, Istanbul Dance Theater Company, 2006. Retrieved from the Personal Archive, Courtesy of Tan Temel \&o Sernaz Demirel Temel

"IDT is a company that strives to fill the gap of dance companies in Turkey. Somehow dance companies are always hard to establish in Turkey. But now we see some slow sparkles. Our main goal is to contribute to the formation of these companies. We have young artists in our group. They need to practice their art. Therefore, our ensemble, is also an establishment for dancers. In new practices in the World, the choreographer currently produces together with the dancer. The purpose of IDT is to enable the dancer to participate in this collaboration. That's why our company is so creative. IDT is not only my company; it is also my dancers' company. We have a very universal perspective on everything. At the same time, we are a company that seeks for its own essence and wants to exist within its culture." (Bay, Milliyet Sanat, 2006, p.46)

IDT completed its preparations in 2005, and upon the invitation of Ismael $\mathrm{Ivo}^{21}$, participated in the dance festival (Biennale Danza, International Festival of Contemporary Dance ${ }^{22}$ ) organized as part of the International Venice Biennale. Geyvan McMillen's work “The Hidden” was staged during the festival where also her statement "Breaking the Veils" was presented. The costume and stage designs of the piece were created by the artist Dilara Akay ${ }^{23}$. Along with this project, Dilara Akay took part as the designer of IDT in all the projects exhibited. The choreography and the statement were welcome with great interest at the Venice Dance Festival. The audience gave McMillen and her team a standing ovation for minutes. At the same time, also the Italian press showed great interest in McMillen's work. Festival Director Ismael Ivo invited the company once again to stage a one-night piece with a larger group at the festival that was to be held in 2006 .

\footnotetext{
${ }^{21}$ https://www.oxfordreference.com/view/10.1093/oi/authority.20110803100014571

22 https://www.labiennale.org/en/dance/2021

${ }^{23} \mathrm{http}: / /$ dilaraakay.com/tr/
} 

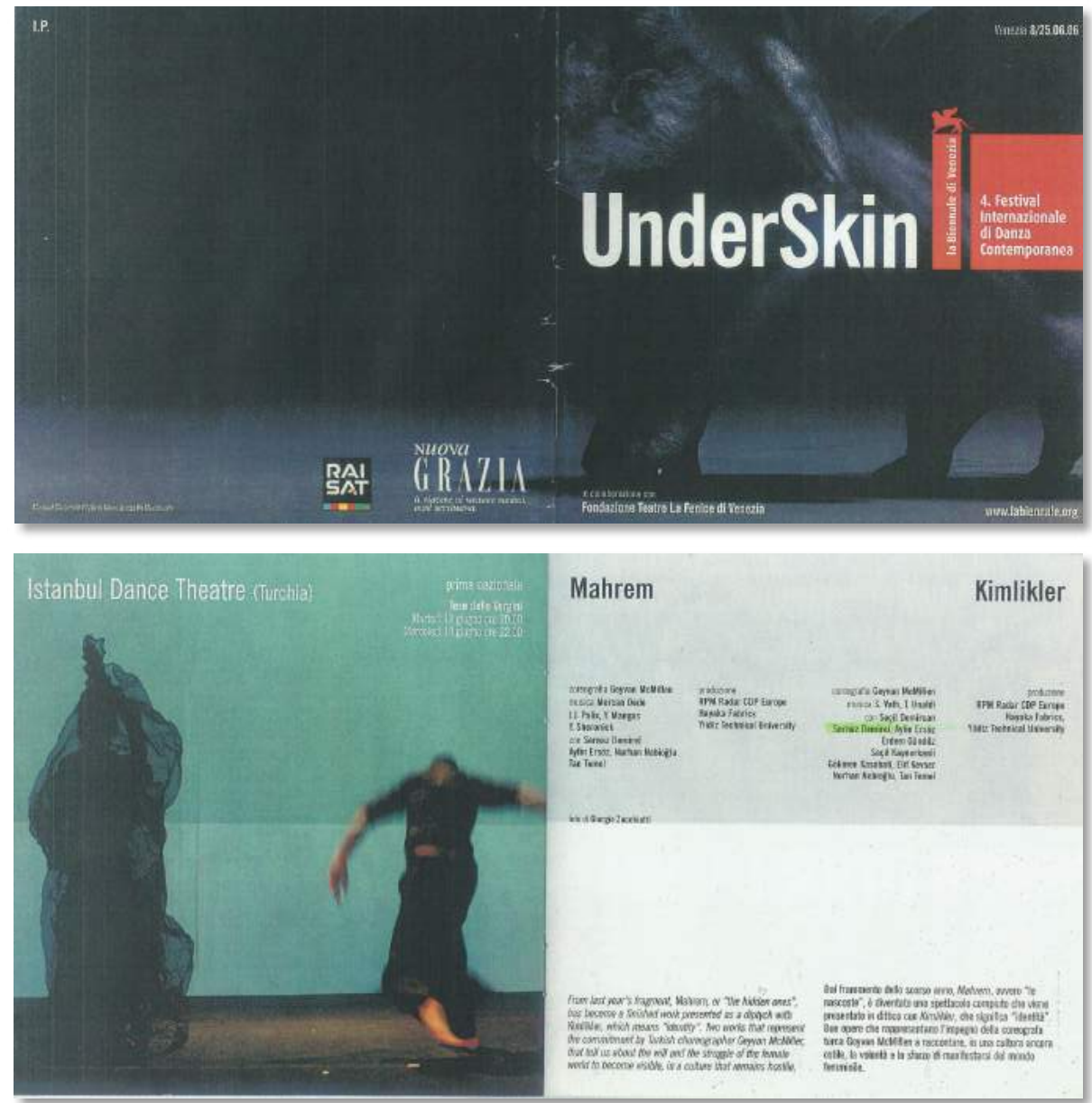

Figure 20.

Biennale Danza Festival Brochure, 2006. Retrieved from the Personal Archive, Courtesy of Tan Temel do Sernaz Demirel Temel

Motivated with the success achieved in the festival, as soon as she returned to Turkey McMillen started to prepare for the next year by auditioning the students she trained. After two successful shows in the festival in 2006, together with her assistants Tan Temel and Sernaz Demirel Temel, McMillen was invited to an education platform organized within the scope of the Venice Biennale for training and choreography courses in 2009 and 2010 (Biennale College, Artistic Training and Internships for Young People, Arsenale della Danza ${ }^{24}$ ).

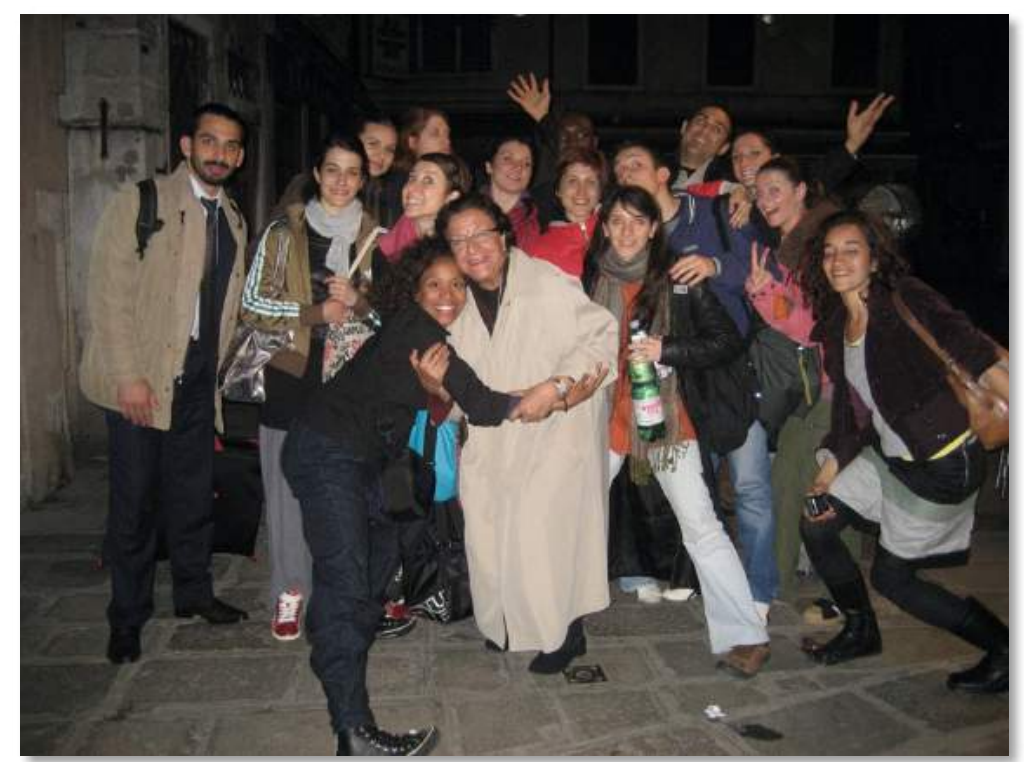

Figure 21.

Geyvan McMillen (Center) Together with Director Ismael Ivo (center back) and Dancers of Biennale Danza Festival, Venice 2009 Retrieved from the Personal Archive, Courtesy of Tan Temel \& Sernaz Demirel Temel 
Ismael Ivo, the director of the festival, brought together groups set up from professional dancers from all over the world with trainers and choreographers of well recognized important European and American companies. At the end of the workshops, lasting 15 days for six months, the final project was ready to be staged. The works of McMillen together with her assistants Tan Temel and Sernaz Demirel Temel were staged in this platform as well.
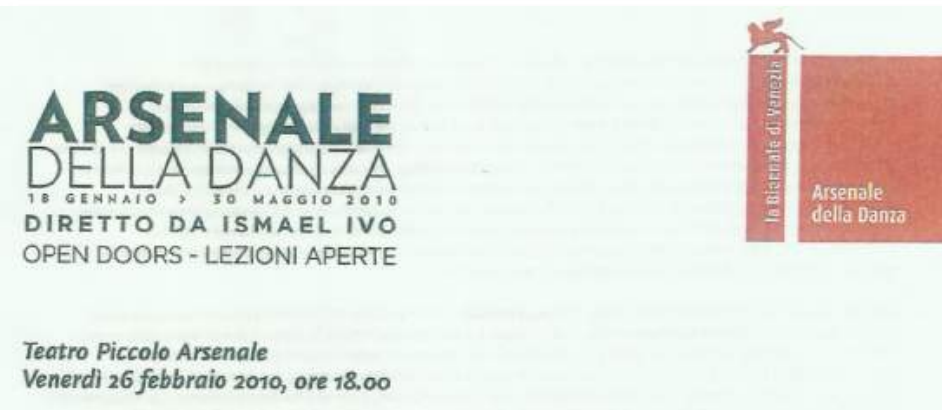

\section{Geyvan McMillen / Tan Temel / Sernaz Demirel Sufismo e la danza dei dervisci rotanti}

Lezione dimostrativa con i donzatori dell'Arsenale della Danza:

Jessica Bova, Ivelice Brown, Antonino Casile, Ariella Maria Casu, Francesco Colaleo,

Veronica Cornacchini, Laura De Nicolao, Sandra Français, Valeria Galluccio, Jan Jarnrich, Roberto Lazzari, Isabella Legato, Chiara Montalbani, Gioia Maria Morisco, Andrea Orlandi, Amandine Petit, Stella Picariello, Claudio Pisa, Stefano Roveda, Teresa Santos,

\section{Figure 22.}

Venice Biennale Contemporary Dance Festival, Arsenale Della Danza Festival Brochure, Venice 2010. Retrieved from the Personal Archive, Courtesy of Tan Temel \& Sernaz Demirel Temel

"Pushing the limits of the body means really knowing and recognizing it. And therefore, dance should not only be regarded as movement. The body is an amazing material if one wishes to express what he/she thinks. That's why we improvise all the time and as we improvise, the body begins to easily convey the stories you think of and want to tell. That's when it turns into an endless material" (Altunok, Cumhuriyet Pazar, 2006, p.16)

IDT continued to stage choreographies in Turkey aside from its shows in Italy. In 2007, they participated in the International Istanbul Dance Festival with the work "Upside/Down", choreographed by Tan Temel. "Upside/Down", of which McMillen was the Art Director and has contributed with a video installation, was one of the first examples of interdisciplinary production in Turkey in which music, film, 3D design and dance choreography were combined. 


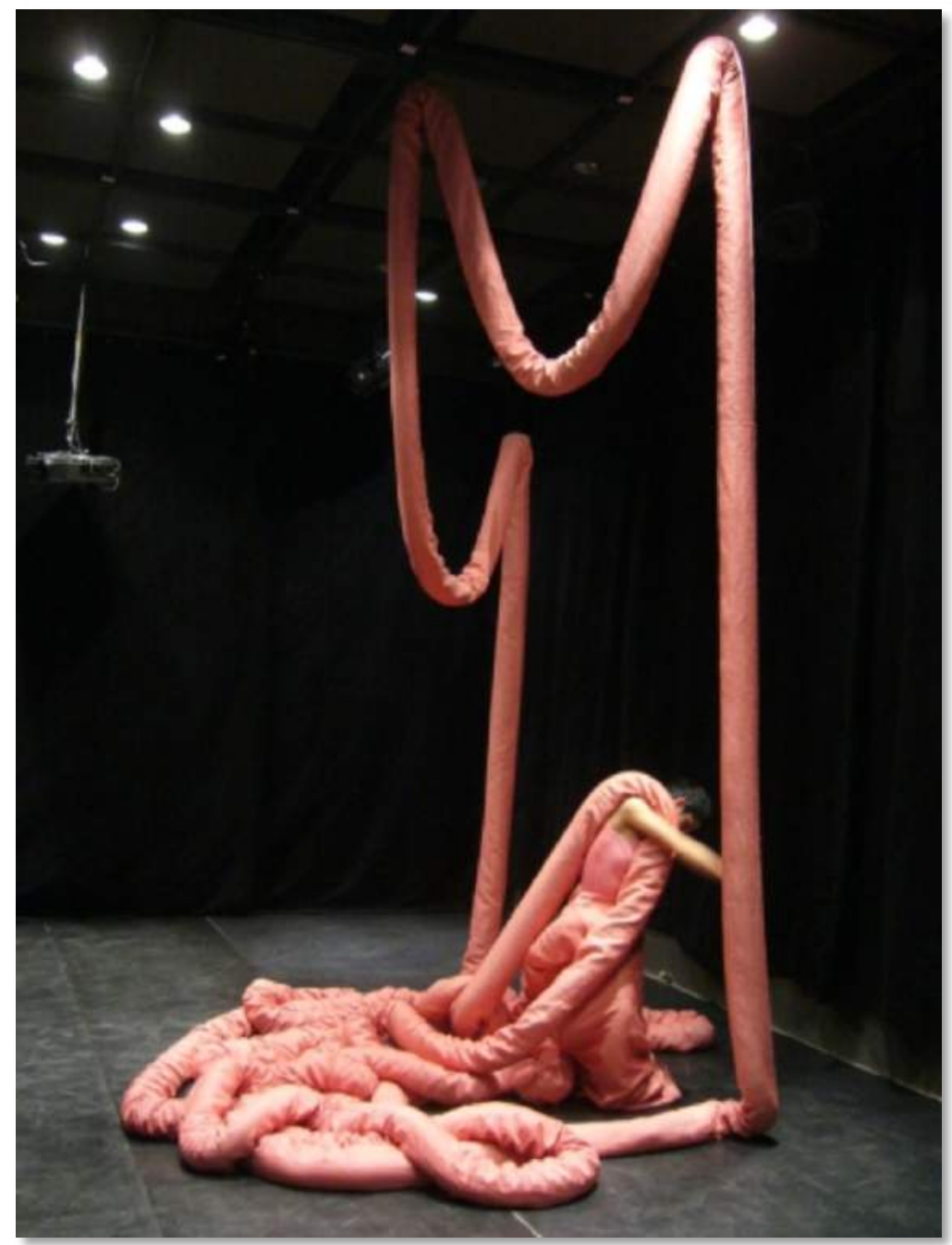

Figure 23.

“Upside/Down”, Choreography by Tan Temel, 3D Design Dilara Akay, Art Director Geyvan McMillen, 2007. Retrieved from the Personal Archive, Courtesy of Tan Temel \& Sernaz Demirel Temel

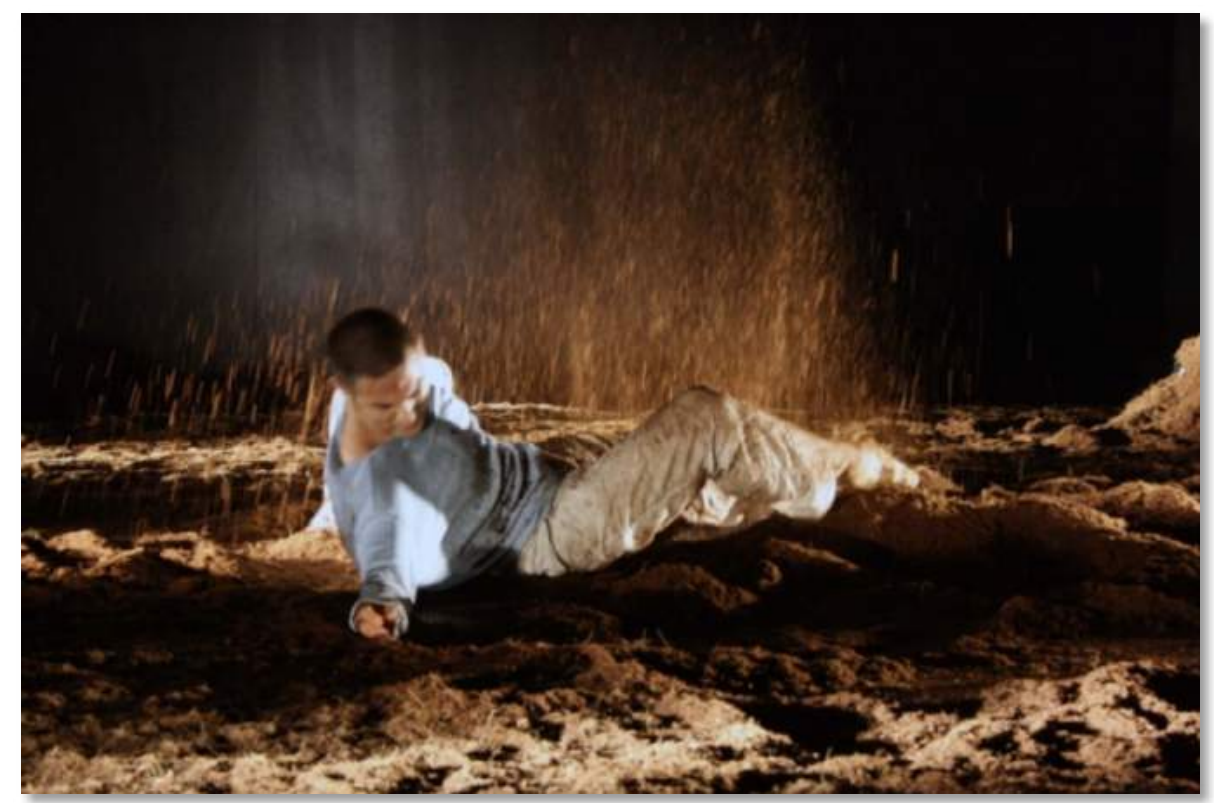

Figure 24.

"Upside/Down”, Choreography by Tan Temel, 3D Design Dilara Akay, Art Director Geyvan McMillen, 2007. Retrieved from the Personal Archive, Courtesy of Tan Temel \& Sernaz Demirel Temel 
IDT introduced the concept of "Dance Installation"25 to the audience for the first time in Turkey with this work. The audience was prepared for a particular atmosphere that would provide the integrity of the choreography just before the beginning of the performance. It was ensured that the audience mentally prepared themselves for a new performance experience.

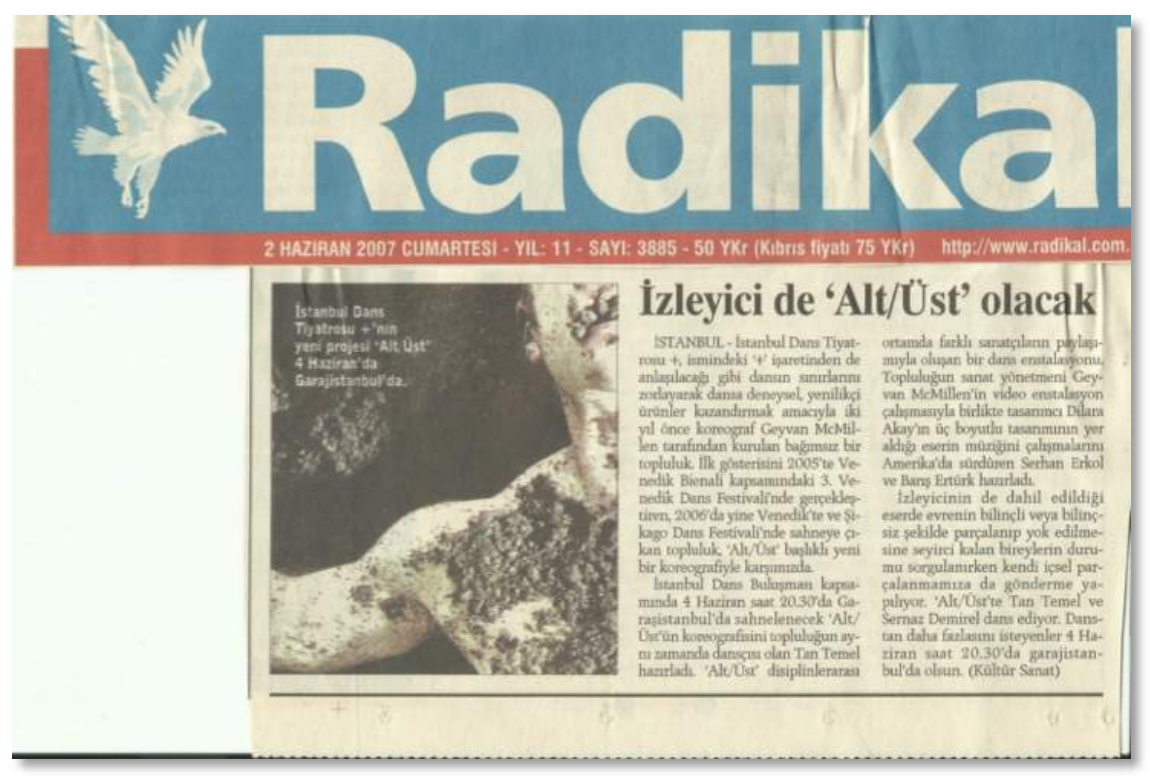

The Audience Will Turn

'Upside/Down'

\section{Figure 25.}

News About IDT Performance "Upside/Down", Radikal Newspaper, 2007. Retrieved from the Personal Archive, Courtesy of Tan Temel \& Sernaz Demirel Temel

In 2008, McMillen decided to prepare a work called "Confrontation" for the $16^{\text {th }}$ International Istanbul Theater Festival. McMillen dedicated the piece to an Italian performance artist Pippa Bacca ${ }^{26}$, who was violently murdered on March 31, 2008 in Gebze, Turkey. Artists who have grown up and lived in these lands were greatly affected by this brutal murder. McMillen was deeply saddened by this event, at a time when she had very close personal relations with Italy. Sernaz Demirel Temel, Chan U Hong (Macau) and Tan Temel danced in the piece.
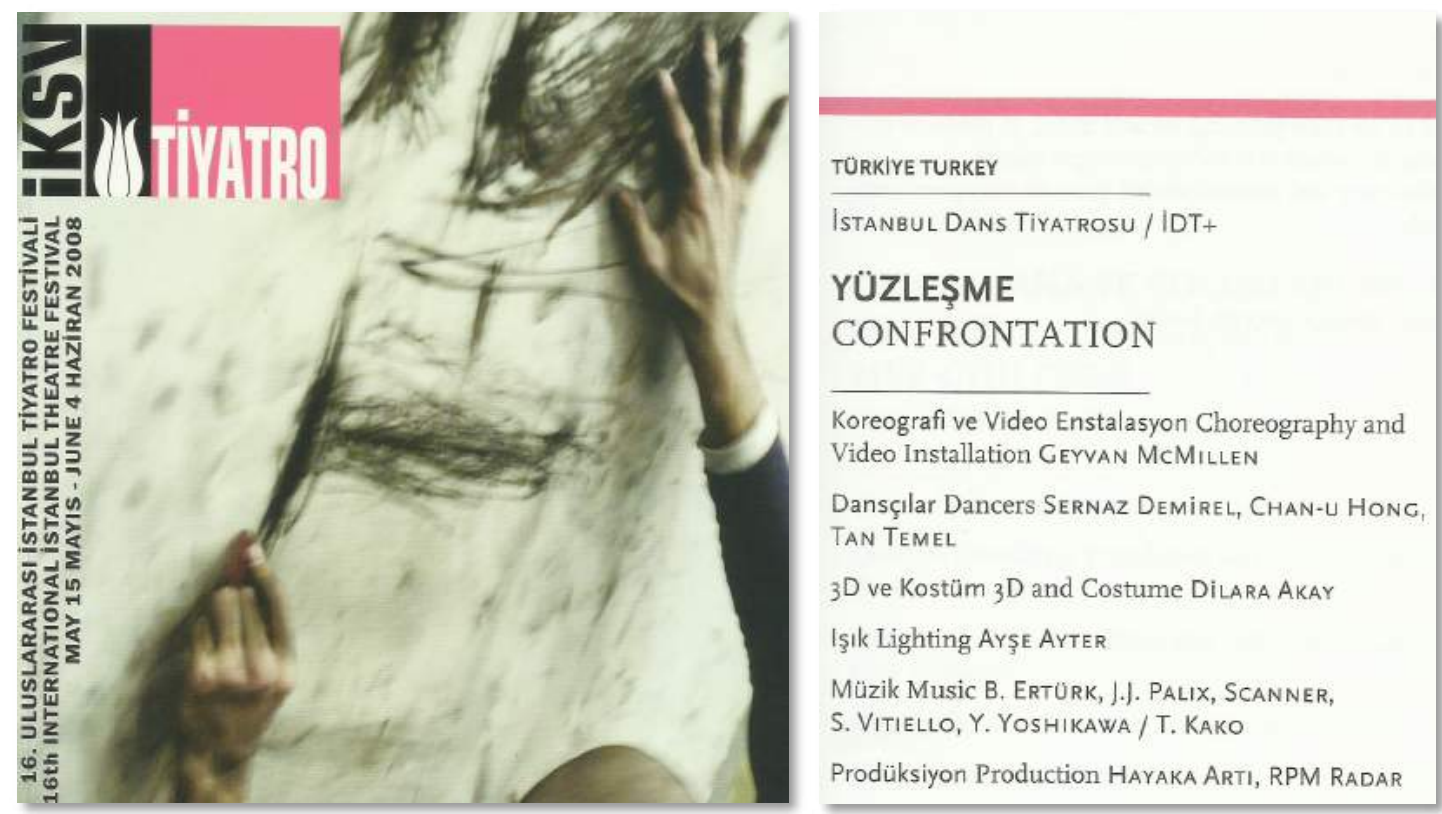

Figure 26.

$16^{\text {th }}$ International Istanbul Theater Festival Brochure "Confrontation" Choreography by Geyvan McMillen, 2008. Retrieved from the Personal Archive, Courtesy of Tan Temel \& Sernaz Demirel Temel

\footnotetext{
${ }^{25}$ Dance Installation: Designing dance choreography by supporting the conceptual and practical approaches of different art disciplines.

${ }^{26}$ https://www.pippabacca.it/category/sposa-in-viaggio/
} 
The work consisted of independent solos of three dancers and a video installation. Mirrors and threads were used as stage design. McMillen separated the dancers from the audience with a material that had mirrors on both sides but at the same time provided permeability due to an interaction with light.

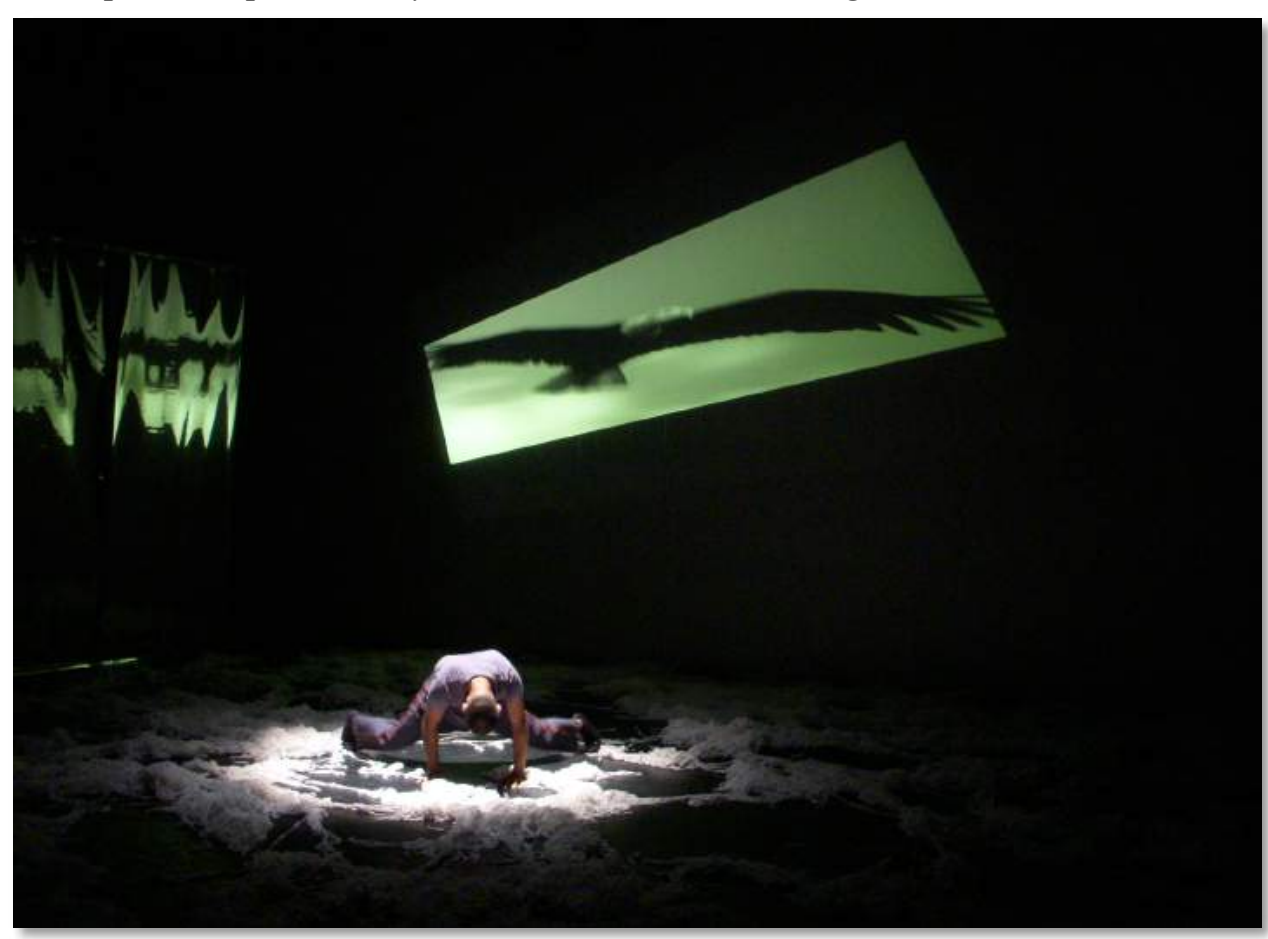

\section{Figure 27.}

"Confrontation" Choreography by Geyvan McMillen, 2008. Retrieved from the Personal Archive, Courtesy of Tan Temel \& Sernaz. Demirel Temel

The audience entering the venue, would come across this mirror covering the downstage and was left alone until the choreography started. Although they were already on stage, as the audience entered the hall, the dancers could only see themselves.

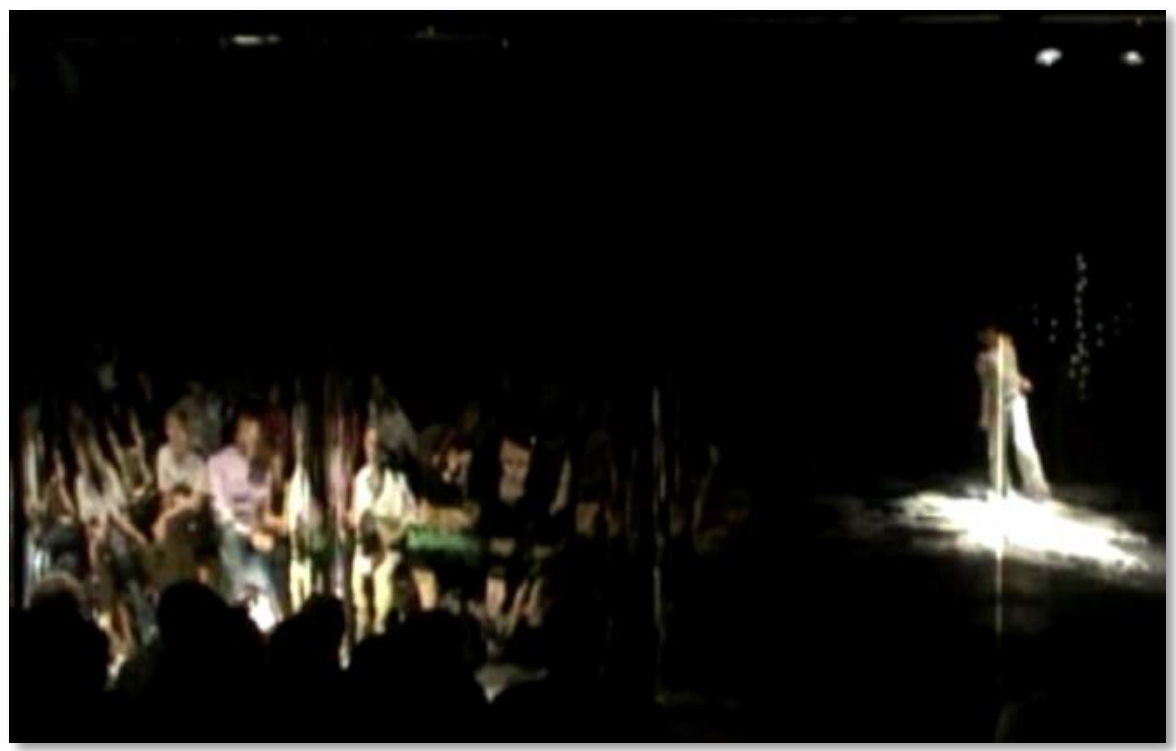

Figure 28.

"Confrontation" Choreography by Geyvan McMillen, 2008. Retrieved from the Personal Archive, Courtesy of Tan Temel \& Sernaz. Demirel Temel

The work was built on the idea of the confrontation of the dancers and the audience with themselves. Sernaz Demirel Temel, wearing the wedding dress designed by Dilara Akay, made the audience watch her ritual of purification with water, with the belief that we all had a share in this tragedy and that we needed to be purified. The strings used on stage, represented the energies we send to the universe, throughout our lives, sometimes intentionally and sometimes unintentionally. Although we are all independent of each other, these energies we create connect us both to each other and to nature in some way, and we all have a responsibility in everything that happens. The piece, 
which was welcome with interest by the audience, offered a different experience and was staged in Macau and Istanbul in 2009.

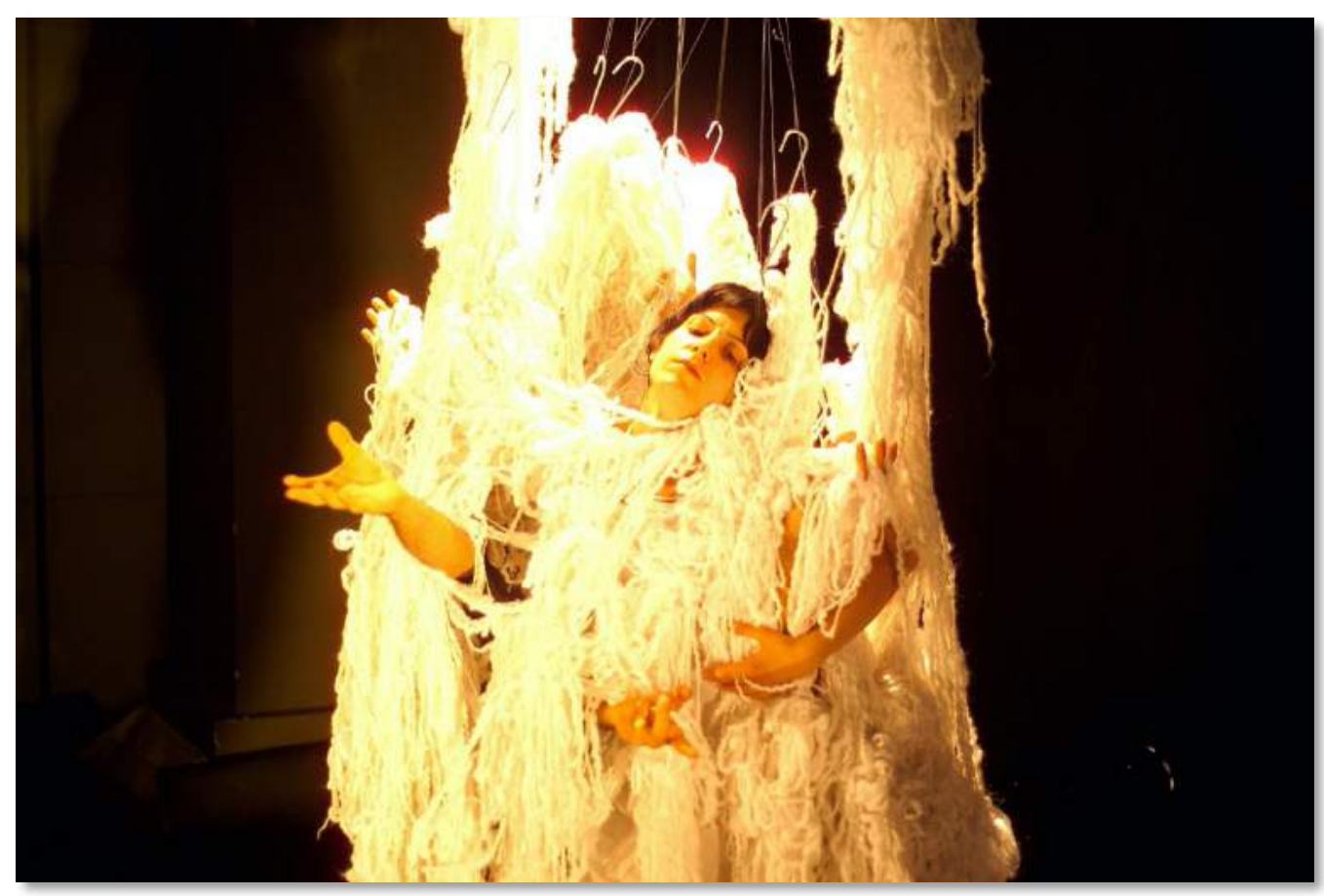

Figure 29.

"Confrontation" Choreography by Geyvan McMillen, 2008. Retrieved from the Personal Archive, Courtesy of Tan Temel \& Sernaz. Demirel Temel

Tan Temel, the choreographer and dancer of the Istanbul Dance Theater Company and Jack Gallagher, the director and choreographer of the Bodies Anonymous (BA) dance company27, which continues to work in Amsterdam, the Netherlands, worked on a joint production for the event program prepared in the scope of the election of Istanbul as the European Capital of Culture in 2010. During the research process that started in 2008, based on their own philosophies, cultural heritage and artistic background, artists began to ask questions about differences in the construction of cultural formations. BeHold Project is an interdisciplinary dance performance that questions the structure of the "clash of civilizations", which has become intensified in the global and political environment, within the framework of media and neighborhood relations. The work has met its audience at the Cemal Reşit Rey Concert Hall in Istanbul and at the Bellevue stage in Amsterdam. 


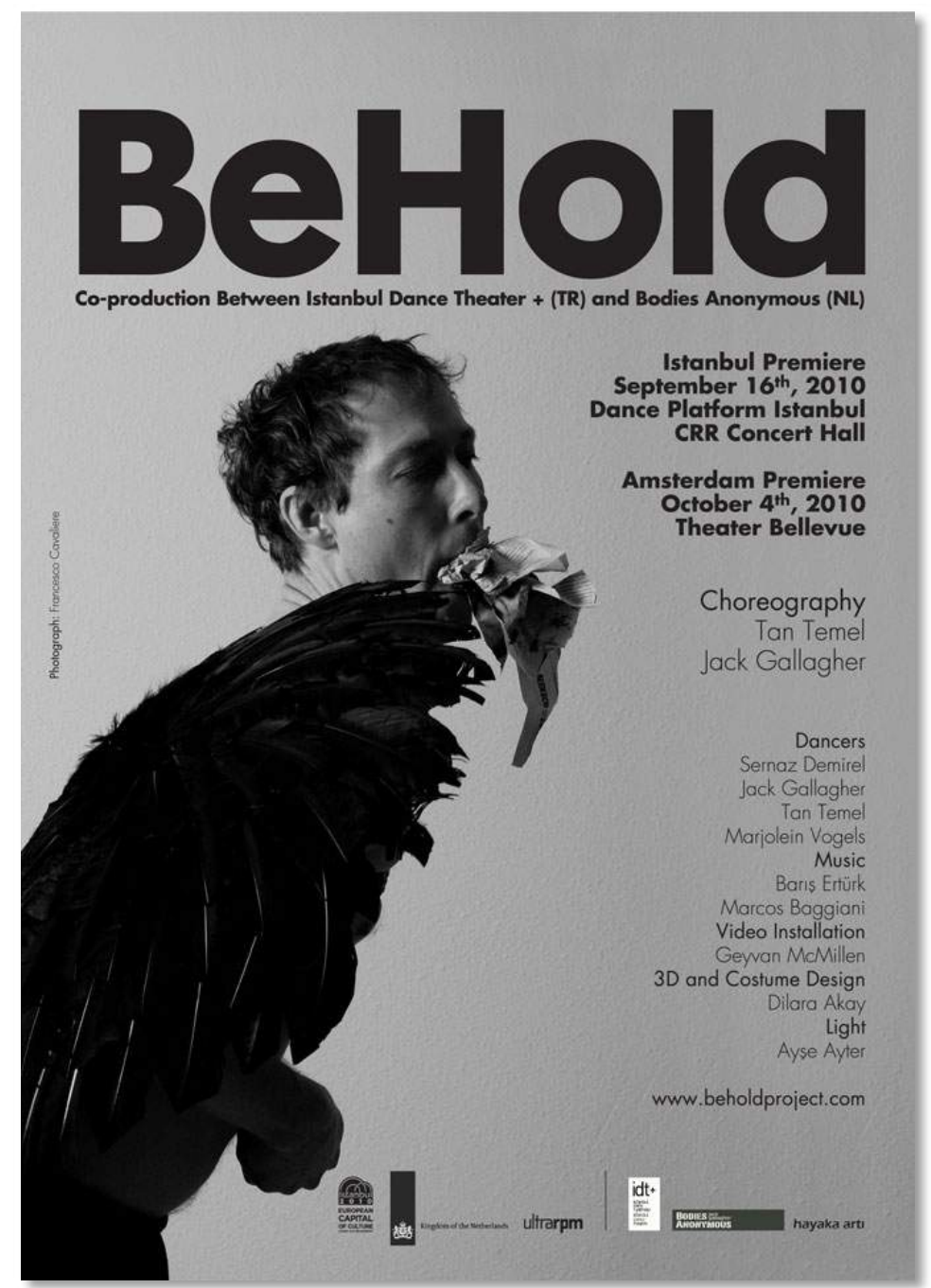

Figure 30 .

"BeHold" Choreography by Tan Temel \& Jack Gallagher, 2010. Retrieved from the Personal Archive, Courtesy of Tan Temel \& Sernaz Demirel Temel

The preparations for the work entitled "Jaded Secrets" began upon an invitation received from the International Theater Festival in 2012. Geyvan McMillen prepared the choreography of this piece together with Ankara Modern Dance Company artist Devrim Ileri Tozkoparan. The dancers in the production were Sernaz Demirel Temel, Tan Temel, Devrim İleri Tozkoparan and Istanbul State Opera and Ballet artist Özerk Tozkoparan. The stage design was created by Dilara Akay. The piece consisted of solos, duets and quartet dances.

The work, which purely revealed the secrets of a life devoted to art under all circumstances, was presenting itself to the audience with four moving bodies. There were some difficulties in the rehearsal process due to problems encountered with regard to the working place. "Jaded Secrets" staged at Garaj Istanbul as part of a festival was welcome with great interest by the audience. 
TÜRKIYE TURKEY

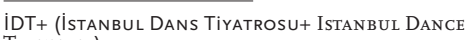
THEATRE+)

\section{YORGUN SIRLAR \\ JADED SECRETS}

Koreografi Choreography by GeYVAN MCMILLEN DeVrim İleri TozKoparan

Sahne Enstalasyonu Stage Installation DiLARA AKAY

Video Enstalasyonu Video Installation G EYVAN MCMILLEN

Dansçוlar Dancers Sernaz Demirel, Devrim Íleri Tozkoparan, Tan Temel, ÖZerk Tozkoparan (IDOB)

Müzik Music ÇEşitli besteciler VARıous Composers

Yapımcilar Producers Hayaka ARTI, ULtRA-Rpm

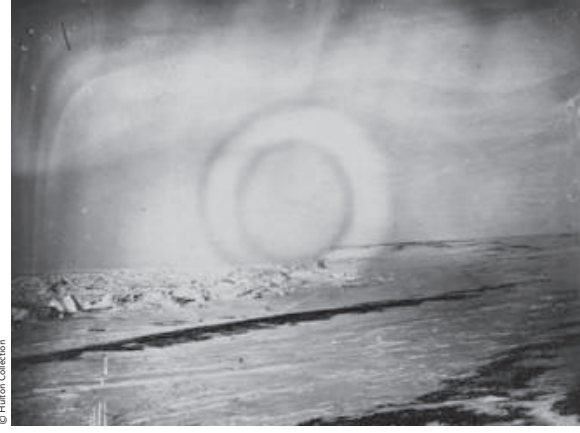

IDT+ Anadolu'nun zengin tarihi ve kültür çeşitliliğinden beslenerek, ulusal ve uluslararası sanat ortamına disiplinlerarası projeler üretmek üzere kuruldu. IDT+'nin sanat yönetmeni McMillen, yıllardır ürettiği çeşitli projelerle eserlerini ulusal ve uluslararası platformlarda sergilemiş, modern dansın Türkiye'de 35 yıldır gelişmesinde katkıda bulunarak öncülük yapmış ve uzun yıllar Devlet Opera ve Baleleri bünyesinde çalışmıştır. Yorgun Sirlar'ın koreografisini Geyvan McMillen ve Devrim Ileri Tozkoparan birlikte gerçekleștirmektedir. Devrim ileri Tozkoparan ADOB Modern Dans

Topluluğu'nda dansçı, eğitmen ve koreograf olarak görev yapmıştır. Halen İstanbul Devlet Opera ve Balesi yapmısçııs olarak çalıșmalarına devam etmektedir. sanatçıIı olarak çalışmalarına devam etmektedir.
Topluluk, Yorgun Sırlar adlı projelerini ise şöyle dile getiriyor: "Gözlerimiz ve ruhumuz çoğu zaman yaradııışın muhteşemliğinin farkında olmasa da, bu olağanüstü olaya her zaman hayranlık duyduk. Geldik gidiyoruz. Var olmak, yok olmak, sırlar ve sırlarımız bizimle birlikte sonsuza kadar..."

- Geyvan McMillen

\section{Figure 31.}

"Iaded Secrets" Choreography by Geyvan McMillen, Devrim Illeri Tozkoparan, 18th Istanbul Theater Festival, 2012. Retrieved from the Personal Archive, Courtesy of Tan Temel \& Sernaz Demirel Temel

"The reason why I called this piece "Iaded Secrets" was because I wanted to get away from this tiring environment as a consequence of my long struggle in the field of dance in Turkey. I preferred to give room to my new occupations that would comfort me. And decided not to produce any choreographies unless I was given the opportunity and environment I wanted." (Geyvan McMillen, Personal Communication, 20 August 2020, Istanbul) 


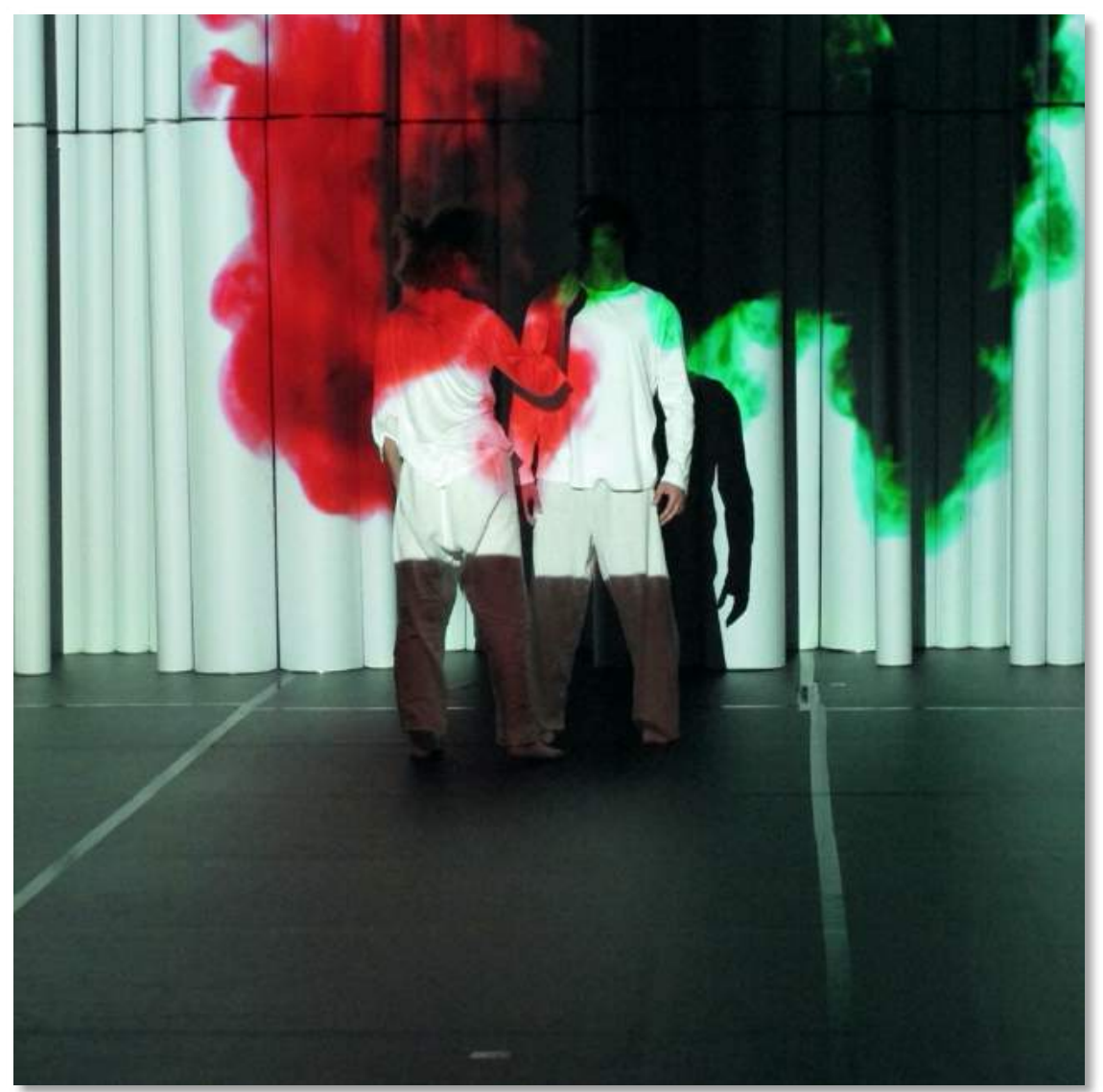

\section{Figure 32.}

"Taded Secrets" Choreography by Geyvan McMillen \&o Devrim İleri Tozkoparan, 18th Istanbul Theater Festival, 2012. Retrieved from the Personal Archive, Courtesy of Tan Temel \& Sernaz Demirel Temel

"Although our eyes and souls are often not aware of the magnificence of our creation, we have always admired this extraordinary event. We come; we go. Existence, nonexistence, secrets and our secrets will be with us forever..." - Geyvan McMillen

\section{Conclusion}

In 1952, Geyvan McMillen joined the Hacettepe State Conservatory, founded by Dame Ninette de Valois ${ }^{28}$, one of the cornerstones of Turkish Ballet history. As a student of Dame Ninette Valois, McMillen had the opportunity to work with many valuable instructors Valois had invited to the school.

From 1960 to 1970, McMillen has danced in many ballet pieces of the Ankara State Ballet's repertoire. Performances of the world-famous Martha Graham Dance Company in Turkey in 1963 has been an important event that has shaped her artistic life. The dancers of Martha Graham Dance Company using their bodies with a dance technique and expressive language she has never seen before, outside the movements of classical ballet, has inspired her urge to seek for the new.

"The Martha Grabam Dance Company came to Turkey and had a couple of beautiful performances at the Ankara Opera. All of a sudden, my horizons largely changed, until that moment both during my education and while working at the Opera, I only knew about classical ballet. I was unaware of any other kind of dance genre or any other educational system. Suddenly seeing on stage, a completely different dance technique, I was very impressed. I said to myself, I want to learn these new dance techniques and produce choreographies now" (Demirel Temel and Temel, 2021, p. 31)

In addition to classical ballet training, McMillen studied modern dance for five years in London and New York. Returning to Turkey at the end of 1974, she served to her country for many years in the development and spread of Turkish dance.

\footnotetext{
${ }^{28}$ In 1947, Dame Ninette de Valois, the founder of the British Royal Ballet, is invited to Turkey. With the efforts of Valois, a ballet school was established in Istanbul Yeșilköy in 1948. The first ballet school in Turkey to operate within the conservatory begins in 1950 with the process of moving the school in Yeșilköy to Ankara. Hacettepe University Ankara State Conservatory Ballet Department was founded in 1950 by Dame Ninette Valois. Valois carries the British ecole to Turkey and invites the dancers of the Sadler Wells Ensemble as ballet instructor to Ankara Hacettepe State Conservatory.
} 
Looking at the history of Turkish ballet, "Çark" a ballet choreographed by Sait Sökmen in 1968, the works of Duygu Aykal the ballet pieces "Çoğul" and "Oluşum" in 1973, "Pembe Kadın" by Oytun Turfanda in 1974, and "Yoz Döngü" in 1975, and "Dance with Debussy", choreographed by Geyvan McMillen for the 1974/75 season, were the first contemporary ballet choreographies based on classical ballet principles of the State Ballet produced according to contemporary interpretations of Turkish choreographers.

As of 1975, McMillen started to give modern technique lessons to aspiring dancers among the Ankara State Ballet artists. She conveyed her knowledge and provided them with the acquaintance of a different dance technique and body language. Her first modern dance piece, "Delta", produced in 1975, was staged in Ankara and Istanbul with the support of the British Council. In later periods, other pieces performed independently were, "Konser" (Concert,1975), “Anadolu'da Gece” (A Night in Anatolia, 1975), "Düet” (Duette, 1975), “Toprağa Ninni” (Lullaby for the Earth, 1976), "Boş Gökyüzü” (Empty Sky, 1976), "Mavi Düşler” (Blue Dreams, 1975/1976) etc. meeting their audiences at the Ankara Contemporary Stage, and stages of Turkish-American Association, German and British Cultural Delegation.

McMillen, continuing to work for the Istanbul State Opera and Ballet since 1977, with the Istanbul State Ballet staged the following pieces: “Öykü” (Story, 1979), "Nijinski ile bir Akşamüstü” (An Evening with Nijinski,19871988), "Meditasyon” (Meditation, 1988/1989), "Sıradışı Değişimler” (Extraordinary Changes), "Bolero”, "Erkin Konçerto” (Erkin Concerto, 1992), "Nemrut'un Dansı” (Nemrut's Dance, 1992), “Anadolu'da Gece” (A Night in Anatolia, 1992), "Mutlu Son" (Happy End, 1992), "Ara Danslar Ara Nağmeler" (In between Dances, In between Tunes, 1997-1998). She produced the choreographies of the pieces "Deli Dolu" (Alive and Kicking, Musical, 1980), The "Sevil Berberi" (Barber of Seville, Opera, 1979), "Karmen" (Carmen, Opera) for the Istanbul State Opera. While working in Istanbul, she prepared "Kaos" (Chaos, 1990) for Ankara Modern Dance Company (MDT) and "A La Tango" for the Ankara State Ballet in 2000.

McMillen together with the independent companies she has founded has staged the choreographies of Ko-yaanis-katsi (1986), “Ajlan'a Sevgiler" (With Love to Ajlan, 1986), "Nideyim Gönlümü” (Oh my Heart), "Dünkü Mektuplar" (Yesterday's Letters), "Ah Şu Caz" (Oh That Jazz, 1996) and has continued to teach at various universities in Istanbul.

In 1998, she established the first Modern Dance Program adopting an alternative education system to conservatories within the Faculty of Art and Design, Department of Music and Performing Arts in Yildız Technical University. With the Yildı Technical University Dance Theater Laboratory Group, she founded at Yıldız Technical University, she aimed to provide students with stage experience and to create a platform where they could produce their own choreographies. She prepared her students from the YTU Dance Theater Laboratory for the CRR Dance Theater (2002-2005), namely a professional platform. CRR Dance Theater Group attracted attention with its successful performances in Turkey and abroad.

McMillen continued to produce with a smaller ensemble with the Istanbul Dance Theater which she founded in 2005. McMillen, who devoted her life to art and education for the academic and artistic development of modern dance art in Turkey, created more than 50 pieces.

\section{"McMillen's dance life bas been a struggle. The artist, despite her constant working and producing, always encountered several difficulties and obstacles and explains this situation as such: T think this is my misfortune in art." (Demirel Temel and Temel, 2021, p.38)}

McMillen saluted her audience for the last time with her piece "Jaded Secrets" in 2012, as part of the 18th Istanbul Theater Festival. While working for "Jaded Secrets", she stated that she would continue one day only if the right environment was presented or otherwise would quit. After all these years of experience, McMillen still has an expectation for improved working and staging opportunities.

It can be considered that the difficulties that McMillen experienced in the early stages of her art which still continue to exist after a long period of 60 years, can be attributed to the fact that dance is still not seen as part of our culture and is not taken as seriously as in the west. For the development of modern dance, it can be said that the legal regulations of the Council of Higher Education of Turkey and regulations in the form of contribution of local governments to the art of modern dance are not sufficient and looking at the systems of developed countries in the art of dance, our culture and art policies definitely need to be reviewed.

The Dance Program established by McMillen at Yıldız Technical University, CRR Dance Theater Company, and Istanbul Dance Theater Company have been the last projects of her career which have contributed greatly to the 
proper development of the art of dance in our country. If all these works could have been maintained by appropriate supports, new dancers, trainers and choreographers performing the art of modern dance on universal scale would have been bred in our country. And this in turn could have brought about new formations and have created solid foundations for the spread of the art of dance in Turkey.

McMillen mentions that modern dance has started in Turkey shortly after England. She always sets as an example England becoming a leading country in the world in this field. With the right policies and systems, the way for development can definitely be paved. With the idea "An artist should always question his/her art in the course of time, adapt it to the conditions of the day and move towards the future." she has repeatedly expressed her belief in the young potential of Turkey.

Feeding on the vision of McMillen, who was granted the "Honorary Award" by the Istanbul Foundation for Culture and Arts (IKSV) ${ }^{29}$ in 2020, we as her students, will continue to put forth each and every effort to create and develop the dance environment in our country she has always hoped for.

\section{Acknowledgement}

The importance of master-apprentice relationship in art education is undeniable. Keeping this in mind, the 25-year period we spent together as Geyvan McMillen's assistants and dancers, was the most valuable and instructive part of our lives. We still continue to learn a lot from McMillen, with her life stretching out to most of the Turkish dance history. This year on the $61^{\text {st }}$ anniversary of her artistic life, we would like to thank our esteemed teacher and master, who has touched many Turkish dancers, for all her endeavors. Each and every effort has been made to present this article as an archival document of record summarizing the valuable work on modern dance carried out under the leadership of Geyvan McMillen. As article writers in Turkey, where it is always troublesome to find resources, long personal interviews with Geyvan McMillen, organizing her personal notes and documents, the research on newspaper/magazine articles, and our personal experiences have been the most essential factors that have motivated us.

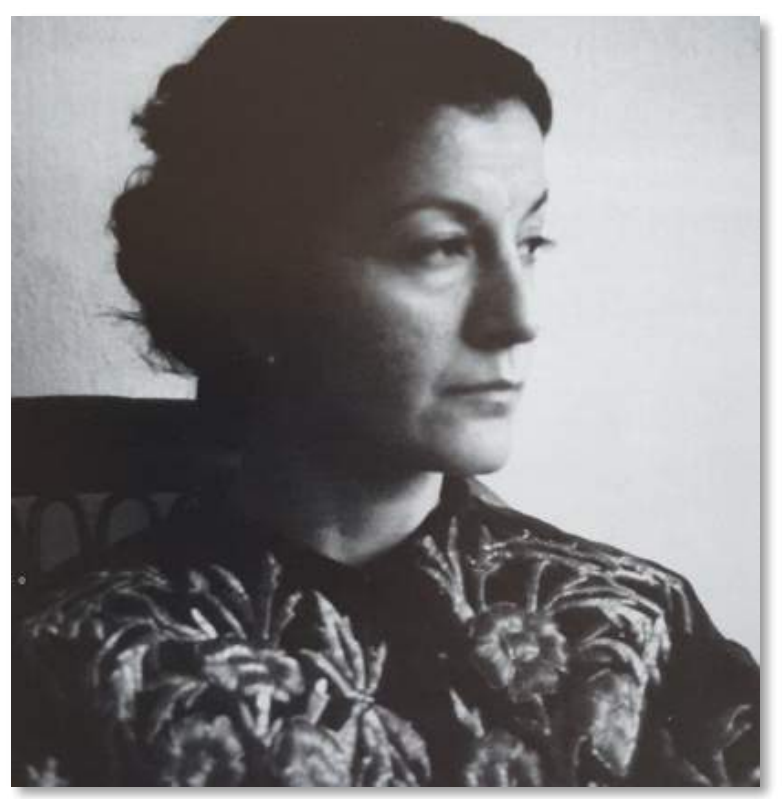

Figure 33.

Geyvan McMillen, 1941. Photo by Paul McMillen

She has graduated from Ankara Hacettepe University State Conservatory Ballet Department in 1960 and in the same year has joined Ankara State Opera and Ballet as a student of Dame Ninette de Valois and a dancer. She has taken lessons from and has assisted trainers such as Molly Lake, Trevis Kemp, Beatrice Fenmen, Ailne Philips, Todd Bolender. After dancing for many years, she has been sent to England with a scholarship from Ankara State Opera and Ballet. She has studied the Martha Graham technique at the London Contemporary Dance School for 4 years with a scholarship won from the British Government in 1970. In 1973, she has studied the Cunningham technique with a one-year scholarship from the Merce Cunningham Dance Company, which had been continuing its studies in New York at that time. Between 1974 and 2006, she has continued to work as a choreographer, instructor and

${ }^{29}$ Istanbul Foundation for Culture and Arts (IKSV) https://tiyatro.iksv.org/tr/oduller/onur-odulleri 
manager at Ankara and Istanbul State Opera and Ballets. McMillen, whose works have been staged in Ankara, Istanbul, Izmir, Mersin State Ballets and in her private companies, has more than fifty original works.

She has been appointed as the chief choreographer of the Istanbul State Opera and Ballet between 1990 and 1993. Between 1979-2002, she has worked as a Dance Director in the organization of First Europalya, First Habitat, as a Dance Consultant of the Ministry of Culture, Member of the Board of Directors of the Istanbul Culture and Art Foundation Music Festival and as a Dance Consultant. From 1974 to 1998, she has taught modern dance techniques at Hacettepe University, Istanbul University, Boğaziçi, Istanbul Technical and Mimar Sinan Universities. In 1998, she has established Yildiz Technical University Faculty of Art and Design, Department of Music and Performing Arts Dance Program and has directed it until 2008. In 2000, she has received her master's degree from the Department of Museology at Yıldız Technical University. Between 2002-2005, she has founded the Cemal Reşit Rey Dance Theater Company and has undertaken its artistic direction. In 2009, she has been granted the "2nd Bimeras Award" by the Istanbul Belgian Consulate General and the Bimeras Cultural Foundation for her contributions to the development of the art of dance in Turkey. From 1974 to 2012, she has exhibited her pieces by means of various projects on national and international platforms. She has participated in dance platforms and festivals held in Turkey, England, Germany, Austria, Netherlands, Italy, the United States, France, and China as a dancer, choreographer and instructor. She has been invited to the Venice Dance Biennale 4 years in a row. In 2016, she has served as a Jury Member of the International Classical Ballet Competition. In 2020, on the 60th anniversary of her artistic life, she has received the "Honorary Award" by the Istanbul Foundation for Culture and Arts (IKSV).

Concentrating on dance and video installations while working on her pieces in recent years, Geyvan McMillen transforms the performances of the Istanbul Dance Theater Group, which she has founded in 2005, into interdisciplinary art events and will continue with her research as long as interesting projects for the development of the art of dance in Turkey continue to exist.

\section{Biodata of Authors}

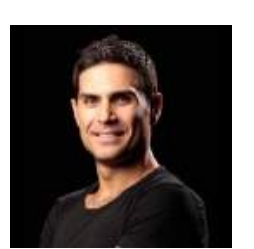

Assoc. Prof. Tan TEMEL; He graduated from MSU State Conservatory Dance Department in 2000. With the scholarship he received from Merce Cunningham Dance School in 2001 he worked on the Cunningham Technique and took part in the works of the Cunningham Dance Company. He continued his work as a dancer and instructor in Cemal Reşit Rey Dance Company founded by Geyvan McMillen between 2003 and 2005, and as a dancer and choreographer in Istanbul Dance Theater Company between 2005-2012 under the direction of Geyvan McMillen. Together with Sernaz Demirel he was granted the "International Chicago Dance Festival Best Choreography Award" in 2007. In 2012 his choreography for Dostlar Theater Company's play "Ben Bertolt Brecht", was awarded with the "Best Theater Award of the Year" by the Theater Critics Association. His choreography for "Supernova" by DOT Theatre was awarded with the "Special Selection Committee Award" at the 17th Sadri Alışık Cinema and Theater Actor Awards and the "Best Production" awards at the $16^{\text {th }}$ Yap1 Kredi Afife Awards. Continuing his creative work in TORK Dance Company, of which he is the co-founder, Tan Temel was the Artistic Director of the L'O.ffcina Dance Company in Florence from 2011 to 2014. He currently is working for the IBO Global (International Baccalaureate Organization) Diploma Programs Dance Curriculum preparation committee. He has completed his Master of Fine Arts in Case Western Reserve University Theater and Dance Department in 2009 and Master of Fine Arts in YTU Art and Design Faculty in 2014. He has been continuing his academic studies at YTU Art and Design Faculty Music and Performing Arts Department since 2001. He teaches at Istanbul University State Conservatory Ballet Department and Bahçeşehir University Conservatory Musical Theater Department. He has been awarded the title of Associate Professor in 2017.

Personal Web Site: https://avesis.yildiz.edu.tr/ttemel E-mail: ttemel@yildiz.edu.tr

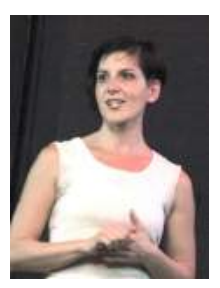

Assoc. Prof. Sernaz DEMIREL TEMEL; she graduated from YTU Modern Dance Program in 2003. She continued her work in the Cemal Reşit Rey Dance Company founded by Geyvan McMillen between 2003 and 2005, and in the Istanbul Dance Theater Company between 2005-2012 under the direction of Geyvan McMillen. Together with Tan Temel she was granted with the "International Chicago Dance Festival Best Choreography Award" in 2007. In 2012 her choreography for Dostlar Theater Company's play "Ben Bertolt Brecht", was awarded as the "Best Theater Award of the Year" by the Theater Critics Association. Her choreography for "Supernova" by DOT Theatre was awarded with the "Special Selection Committee Award" at the 17th Sadri Alışı Cinema and Theater Actor Awards and the "Best Production" awards at the $16^{\text {th }}$ Yap 1 Kredi Afife Awards. She has completed her Master of Fine Arts in Case Western 
Reserve University Theater and Dance Department in 2009 and Master of Fine Arts in YTU Art and Design Faculty in 2014. She currently continues to work as a choreographer, dancer and instructor in the TORK Dance Company, which she is the co-founder of. She has been continuing with her academic studies at YTU Art and Design Faculty Music and Performing Arts Department since 2004. She has been awarded the title of Associate Professor in 2018.

Personal Web Site: https:/ /avesis.yildiz.edu.tr/sernazd E-mail: sernazd@yildiz.edu.tr

\section{References}

Altunok, Ö., (2006). Life is within the Movement, Cumhuriyet Sunday Interview, 2 July 2006, number 1058.

Atmaca, E., (2006). Questioning Turkey's Privacy, Radikal Newspaper Culture / Art, 13 June 2006.

Bay, Y., (2006). Interview: Istanbul Dance Theater in Venice, Milliyet Newspaper Art, June 2006, Istanbul.

Deleon, J., (1990). Turkish Ballet in the Republican Period, Boğaziçi University, Istanbul.

Demirel, Temel S., \& Temel, T., (2021). First Steps of Modern Dance in Turkey, Eurasian Academy of Sciences Eurasian Art and Humanities Journal, 14, 27-43.

McMillen G., (2002). A Post-Republican Dance Art Department Proposal for a Modern Art Museum to be established in Turkey. Master's Thesis, YTU Social Sciences Institute Art and Design Department Museology Program.

State Opera and Ballet General Directorate Special Publication, (2010). Turkish Ballet in its 60 th Year, T.C. Culture and Tourism Ministry State Opera and Ballet General Directorate, $2^{\text {nd }}$ Edition.

Temel T., (2006). What happened to CRR Dance Theater Company?, Sempatik Dance, Monthly Dance Culture and Body Arts Journal, 4, 42-43. Istanbul.

This article was compiled from interviews with Geyvan McMillen in 2020 and the personal notes of Geyvan McMillen. For photographs and visuals, the personal archives of Geyvan McMillen, Tan Temel and Sernaz Demirel Temel were used.

\section{Web References}

www.torkdans.com

www.istanbuldanstiyatrosu.com

http://dilaraakay.com/tr/

http://tomuratagok.com/biyografi.php?l=en

http://www.sts.yildiz.edu.tr/sayfa/1/Hakkımızda/85

YTÜ Library Catalog, Master Thesis of Geyvan McMillen

http://yordam.ktp.yildiz.edu.tr/yordambt/yordam.php?sayfa $=$ sayfaArama\&aDemirbas $=0005792$

https://www.lcds.ac.uk/lcds-homepage

https://www.princeton.edu/news/2009/05/11/internationally-renowned-artists-appointed-head-lewis-center-programs

https://www.folkwang-uni.de/home/tanz/izt/geschichte/lutz-foerster

https://tr.wikipedia.org/wiki/Arda_Aydoğan

https://ekitap.ktb.gov.tr/TR-80133/mdt-doguyor.html

http://istanbuldanstiyatrosu.com/index.php

https://kultur.istanbul/kultur-a-s/

https://www.oxfordreference.com/view/10.1093/oi/authority.20110803100014571

https://www.labiennale.org/en/dance/2021

https://www.labiennale.org/en/biennale-college

https://www.pippabacca.it/category/sposa-in-viaggio/

https://nl.linkedin.com/company/bodies-anonymous

https://www.iksv.org/en/

https://tiyatro.iksv.org/en/awards/honorary-awards 